\title{
Review \\ The Role of Long Non-Coding RNAs (lncRNAs) in Female Oriented Cancers
}

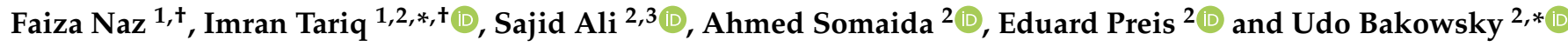 \\ 1 Punjab University College of Pharmacy, Allama Iqbal Campus, University of the Punjab, \\ Lahore 54000, Pakistan; faizanazrph@gmail.com \\ 2 Department of Pharmaceutics and Biopharmaceutics, University of Marburg, Robert-Koch-Str. 4, \\ 35037 Marburg, Germany; sajidalichishti@gmail.com or sajid.ali@kemi.uu.se (S.A.); \\ somaida@staff.uni-marburg.de (A.S.); eduard.preis@pharmazie.uni-marburg.de (E.P.) \\ 3 Angström Laboratory, Department of Chemistry, Uppsala University, 75123 Uppsala, Sweden \\ * Correspondence: imran.pharmacy@pu.edu.pk (I.T.); ubakowsky@aol.com (U.B.) \\ + Authors contributed equally.
}

check for updates

Citation: Naz, F.; Tariq, I.; Ali, S.; Somaida, A.; Preis, E.; Bakowsky, U. The Role of Long Non-Coding RNAs (lncRNAs) in Female Oriented Cancers. Cancers 2021, 13, 6102. https://doi.org/10.3390/ cancers13236102

Academic Editor: Lyndsay Rhodes

Received: 25 October 2021

Accepted: 30 November 2021

Published: 3 December 2021

Publisher's Note: MDPI stays neutral with regard to jurisdictional claims in published maps and institutional affiliations.

Copyright: (c) 2021 by the authors. Licensee MDPI, Basel, Switzerland. This article is an open access article distributed under the terms and conditions of the Creative Commons Attribution (CC BY) license (https:/ / creativecommons.org/licenses/by/ $4.0 /)$.
Simple Summary: Breast and gynecological cancers, broadly termed as female-oriented cancers, are the primary cause of death among females in developed and developing countries. Tumor invasion and metastasis cause the aggressiveness of these cancer types. The occurrence and frequency of women's cancers are associated with genetics, personal lifestyle, body shape, age, menopause status, history of exposure to carcinogens or viruses, and geographical habitat. Moreover, ncRNAs, especially lncRNAs, play an essential role in regulating cellular functions within such cancers. LncRNAs can play dual roles. They can either exert tumor-suppressive or oncogenic functions in women's cancers. Accumulating evidence suggests that lncRNAs can be promising prognostic and diagnostic biomarkers and therapeutic targets in cancers. Thus, understanding the mechanism and role of lncRNAs might provide new opportunities for diagnosing and treating female-oriented cancers. In this review, we discuss the worldwide incidence of breast and gynecological cancers, including endometrial, cervical, ovarian, vaginal, vulvar cancers, and GTN among women. We further provide various perspectives on the association of some lncRNAs, i.e., HOTAIR, NEAT1, H19, MALAT1, and MEG3, in terms of invasion, proliferation, metastasis, apoptosis, and drug resistance of breast and gynecological cancers based on recent discoveries. Finally, we present insight and prospects into the potential of these lncRNAs for evaluating the prognosis, diagnosis, and treatment of such cancers.

Abstract: Recent advances in molecular biology have discovered the mysterious role of long noncoding RNAs (lncRNAs) as potential biomarkers for cancer diagnosis and targets for advanced cancer therapy. Studies have shown that lncRNAs take part in the incidence and development of cancers in humans. However, previously they were considered as mere RNA noise or transcription byproducts lacking any biological function. In this article, we present a summary of the progress on ascertaining the biological functions of five lncRNAs (HOTAIR, NEAT1, H19, MALAT1, and MEG3) in female-oriented cancers, including breast and gynecological cancers, with the perspective of carcinogenesis, cancer proliferation, and metastasis. We provide the current state of knowledge from the past five years of the literature to discuss the clinical importance of such lncRNAs as therapeutic targets or early diagnostic biomarkers. We reviewed the consequences, either oncogenic or tumor-suppressing features, of their aberrant expression in female-oriented cancers. We tried to explain the established mechanism by which they regulate cancer proliferation and metastasis by competing with miRNAs and other mechanisms involved via regulating genes and signaling pathways. In addition, we revealed the association between stated lncRNAs and chemo-resistance or radio-resistance and their potential clinical applications and future perspectives.

Keywords: lncRNAs; breast cancer; gynecological cancers; HOTAIR; NEAT1; H19; MALAT1; MEG3 


\section{Introduction}

The long non-coding RNAs (lncRNAs) are one of two basic classes of the non-coding RNAs (ncRNA), arbitrarily defined as ncRNA transcripts with at least 200 base pairs (bp) that do not encode proteins [1]. It has been estimated from ENCODE project data that around $70-80 \%$ of the human genome undergoes transcription, but out of it, only $2 \%$ genome codes for proteins. The remaining transcribed RNAs are ncRNAs whose functions have not been completely recognized yet. However, it is seen to be involved in the regulation of gene expression at transcriptional, post-transcriptional, or translational levels and various other diversified functions in cells as well $[2,3]$.

By next-generation sequencing, tens of thousands of lncRNA loci have been identified from eukaryotes to humans. The current Gencode annotation approximates nearly 17,952 lncRNA genes and 48,438 transcripts in humans, widely associated with cellular processes during normal development and physiology $[4,5]$. They are very heterogeneous as their transcripts may carry nucleotides from several hundred to several thousand [6]. Like mRNAs, they are $5^{\prime}$-capped, polyadenylated, often spliced, and usually transcribed by RNA polymerase II and III [7]. The lncRNAs are found within the cytoplasmic or nuclear fractions [8,9]. Cytoplasmic lncRNAs are generally involved in regulating mRNA turnover, alternative splicing, post-transcriptional regulation, protein stability, microRNA sponging, and the regulation of signaling pathways [10]. Nuclear lncRNAs, however, regulate the cellular processes by interacting with chromatin architecture [11].

Usually, IncRNAs do not have codon preservation constraints and demonstrate only modest primary sequence conservation. Thus, such sequences of lncRNAs seem to be less significant than their secondary or tertiary structures, and in most cases, their functions are seen to be reliant on their structural conservation rather than sequence conservation $[12,13]$. Previously, lncRNAs were thought to lack the protein-coding ability, but currently, it is found that they can have short open reading frames (sORFs) [14]. Recent studies have discovered a variety of IncRNAs with sORFs that can encode small functional peptides in the human body, which can regulate cellular metabolism, muscle function, and the suppression of cancer growth [15].

Despite the normal physiological regulation, disruption of lncRNA's expression has also been intrinsically linked with the occurrence and development of a range of diseases, including cancer. Hence, it led to the raised interest in studying lncRNAs with the prospect of discovering novel therapeutic and diagnostic strategies [16]. Worldwide, both in highincome or middle-income countries, cancer represents one of the most common causes of death among women. Risk factors for female-oriented cancers can be classified into two main classes: cancers associated with exposures also present in men, and forms of cancers unique to women [17]. Moreover, changes in reproductive patterns, such as later age at first childbirth and lower parity, have contributed to higher female cancer burden worldwide [18]. Several female organs are prone to be affected by different types of cancers. Cancers of the reproductive system, such as the ovarian, uterine, cervical, fallopian tube, vaginal, vulvar, and gestational trophoblastic cancers, can be summarized as gynecological cancers $[19,20]$. Collectively gynecologic and breast cancers can be termed as female-oriented cancers.

The expression profiles of lncRNAs are considered important in female-oriented cancers. Many of the lncRNAs are revealed to be involved in various imperative processes of such cancers, including genesis, cancer development, proliferation, invasion, metastasis, and drug resistance, while some others exhibited inhibition of these processes. Thus, by demonstrating either tumorigenesis or tumor-suppressive roles, the aberrant expression of lncRNAs can significantly contribute to the development of such cancers [21]. At present, 172,216 lncRNA transcripts and 96,308 lncRNA genes, influencing a wide variety of cellular biological processes and the status of cancers in females, have been identified [22].

Previously, the involvement of various lncRNAs has been studied individually by multiple researchers in breast cancer and various gynecological cancers in women, but no one discussed it mutually in the perspective of female-oriented cancers. Therefore, in this 
article, we highlight the role of various lncRNAs and specifically five lncRNAs-HOTAIR, NEAT1, H19, MALAT1, and MEG3 - in cancers unique to women, including breast and gynecological cancers.

\section{Incidence of Female-Oriented Cancers}

Worldwide, cancer is considered one of the most common causes of death in females. According to WHO statistics, the incidence of breast cancer is much higher than any other women's cancer. However, they are spreading with increased rates day by day (Figure 1). The determination and early detection of cancer and the discovery of new and more effective treatment strategies might help control morbidity and mortality rates.

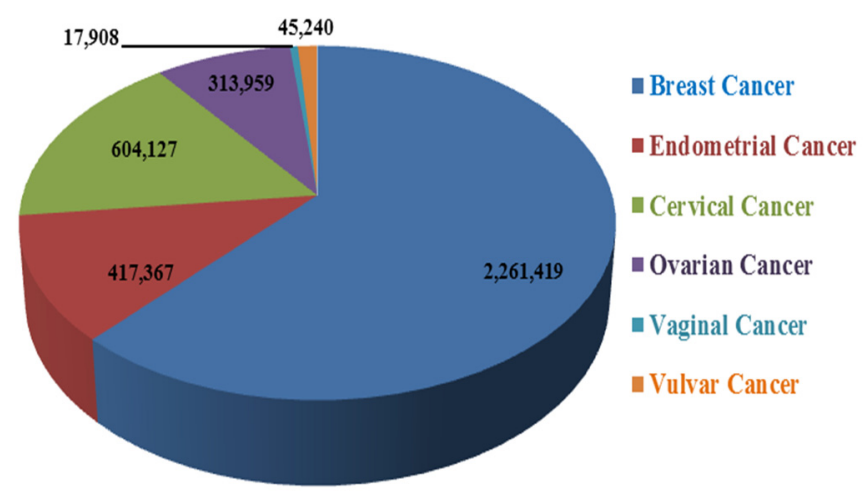

Figure 1. Worldwide incidence of female-oriented cancers according to WHO calculations.

\subsection{Breast Cancer $(B C)$}

Breast cancer (BC) is the most diagnosed form, with over 2 million cases reported annually, whereas lung cancer, in comparison, is the second most common cause of death because of the malignancy of cancerous cells [23]. Ductal hyperproliferation usually causes the onset of breast tumors, which leads to benign tumors or even metastatic carcinomas because of the interplay of persistent stimulation and different carcinogenic factors. As a part of tumor microenvironments, stromal cells and macrophages play a vital role in breast cancer development and progression [24]. Macrophages can promote angiogenesis and empower cancerous cells' immune resistance by creating a mutagenic inflammatory microenvironment [25]. Similarly, epigenetic modifications such as DNA methylation in the tumor microenvironment have been detected to enhance the risk of carcinogenesis [26]. Moreover, cancer stem cells (CSCs), having self-renewal abilities, are observed to be associated with BC initiation, immune escape, recurrence, and exhibited resistance to chemo and radiotherapy [27].

\subsection{Gynecological Cancers}

\subsubsection{Endometrial Cancer (EC)}

Different organs of the female reproductive system are also affected by cancer. The most prevalent gynecological cancer is endometrial cancer (EC) of the uterus, with over 61,000 women diagnosed each year in the USA [28], and an estimated 320,000 new cases and 76,000 deaths reported worldwide in 2012 [29]. EC cultivates in the uterine inner lining from the glandular epithelial sheet, which covers the luminal surface and releases substances needed for normal menstruation or embryonic development [30]. In addition to obesity, altered hormonal levels, reproductive factors, and genetic predispositions are also recognized as EC's major risk factors. EC is genetically heterogeneous, apart from a patient's subgroup belonging to a cancer predisposition syndrome, i.e., Lynch Syndrome, triggered by the germline alterations of DNA mismatch repair genes such as MLH1, PMS2, MSH2, and MSH6. EC also exhibits a high frequency of several other germline mutations in cancer predisposition genes [31]. 


\subsubsection{Cervical Cancer (CC)}

Globally, CC is statistically calculated as the fourth most prevalent form of cancer plus the fourth foremost cause of cancer deaths in females, right after breast, colorectal, and lung cancers. According to the data of Lancet Global Health, nearly 570,000 females faced cervical cancer, of which 311,000 females died in 2018 [32]. Infections with high-risk human papillomaviruses (HPV) are the leading cause of CC. Thus, HPV screening and anti-HPV vaccination programs are considered effective disease prevention strategies [33]. The histological subtypes of CC are adenocarcinoma (25\%) and squamous cell carcinoma $(70 \%)$ [34]. While recognizing the pre-cancerous lesions, a Pap smear test can help identify early changes in cervical epithelium and the early stage of invasive CC [35].

\subsubsection{Ovarian Cancer (OC)}

OC is relatively rare compared to other women's cancers but poses the highest cancer mortality rate. The incidence of OC has been estimated at 11.7-12.1 per 100,000 in Europe and USA, with a lower disease rate in the Middle East and Asia [36]. OC's pathology encompasses a heterogeneous group of malignancies originating in the germ cells, epithelial cells, fallopian tube, and mesenchyme that differ in etiology, molecular biology, and several other characteristics. However, approximately ninety percent of OCs have epithelial origin [37]. Most patients (60\%) are diagnosed with advanced disease progression, leading to a significant mortality rate. Thus, improved prevention and early detection have always been the research priority, as early disease diagnosis results in a higher survival rate $(93 \%)$ [38].

\subsubsection{Primary Fallopian Tube Carcinoma (PFTC)}

PFTC is rare and causes around $0.14-1.8 \%$ of all gynecological malignancies. However, PFTC is similar to OC in clinical diagnosis and cannot be distinguished pre-operatively [39]. PFTC seems like a cystic-solid or a solid adnexal mass that looks like an epithelial ovarian cancer (EOC). Based on preoperative images, it may lead to increased chances of being misdiagnosed as EOC. However, MRI has been advanced to differentiate PFTC from EOC by recognizing the distinctive features of PFTC, such as hydrosalpinx, hydrosalpinx with mural papillary nodules, and intrauterine fluid accumulation [40].

\subsubsection{Vaginal Cancer (VC)}

VC is relatively uncommon, comprising about $3 \%$ of all gynecologic malignancies, and nearly 3000 cases are diagnosed in the United States annually, with approximately 900 deaths [41]. Mainly, VC occurs in older or postmenopausal women because of high-risk HPV infection; however, it has also been reported in younger women [42].

\subsubsection{Vulvar Cancer (VC)}

$\mathrm{VC}$ is considered the twentieth most prevalent cancer in women, with estimated 6190 cases reported in 2018, and the number is still increasing at the rate of $0.6 \%$ annually, but with a comparably decreased survival rate. This disease is mainly diagnosed in older women with a median age of 68 years. Vulvar squamous cell carcinoma (VSCC) is seen to be the utmost common malignancy among female vulvar cancers, constituting above $90 \%$ of all vulvar malignancies of females [43,44]. It is usually believed that VSCC has two etiological pathways, i.e., genetic alterations including p53 mutations or p16INK4a silencing and high-risk HPV-dependent routes [45].

\subsubsection{Gestational Trophoblastic Neoplasia (GTN)}

The development of malignant cancerous cells after any type of pregnancy is known as GTN, a rare gynecological cancer with 2 cases in 1000 pregnancies reported in Japan and Southeast Asian countries, while 1 in 1500 pregnancies in the United States [46]. GTN occurs during pregnancy and is characterized as benign lesions produced by abnormal trophoblastic proliferation. GTN consists of a wide array of interdependent tumors which 
develop after abnormal reproduction of trophoblastic tissues. Some examples are invasive hydatidiform mole (HM), epithelioid trophoblastic tumor (ETT), malignant choriocarcinoma tumors as well as placental site trophoblastic tumors (PSTT) [47,48].

\section{LncRNAs: Classification and Biogenesis}

\subsection{Classification}

lncRNAs are often classified into two major categories, (A) linear lncRNAs and

(B) circular lncRNAs (circRNAs), as mentioned in Figure 2 [49].

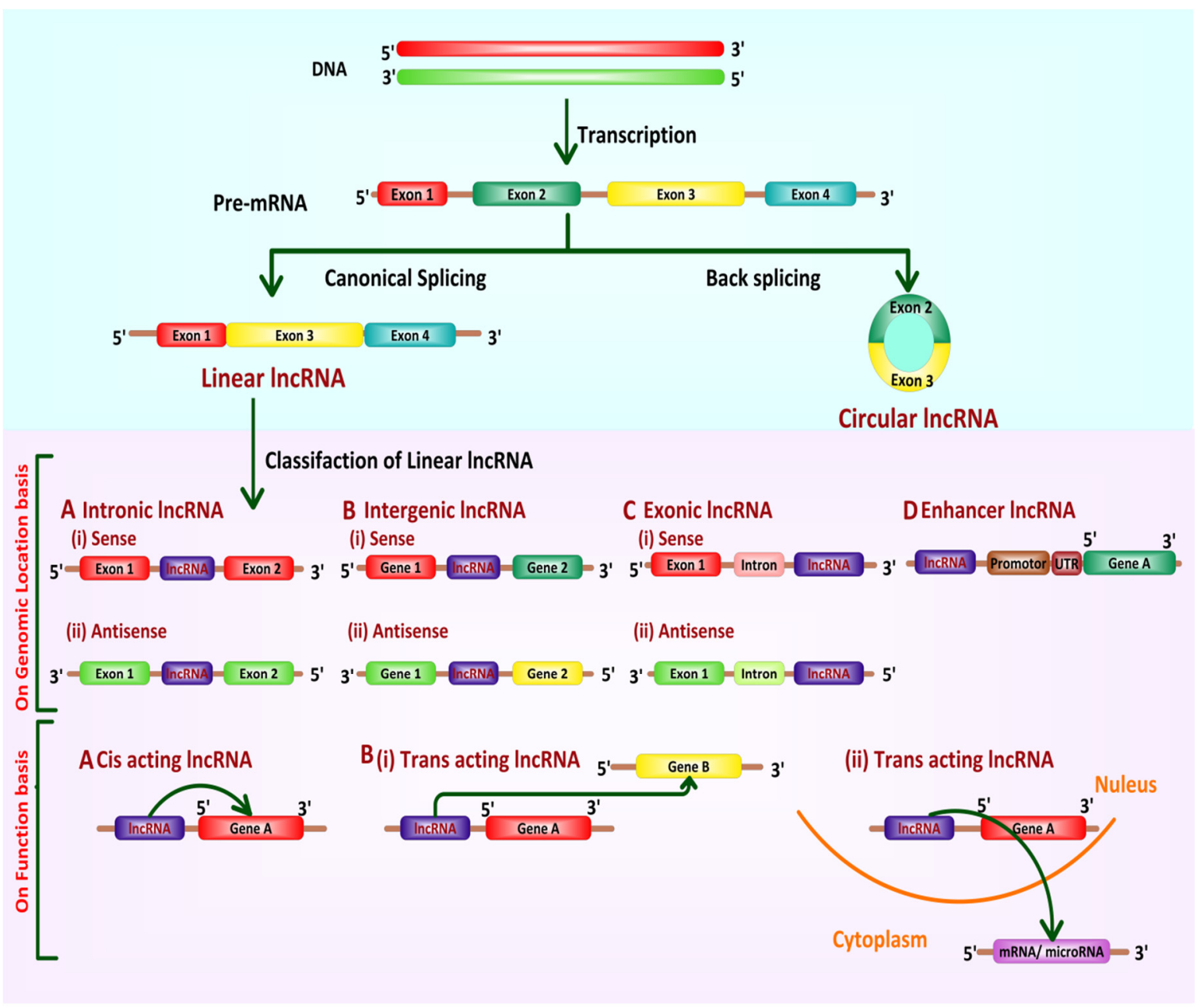

Figure 2. Biogenesis and classification of lncRNAs. Canonical splicing produces linear lncRNA while circular lncRNA is made via back splicing. Linear lncRNAs are further categorized based on their genomic location, direction of transcription (A= (i) Sense and (ii) Antisense intronic lncRNA, B = (i) Sense and (ii) Antisense intergenic lncRNA, C = (i) Sense and (ii) Antisense exonic lncRNA, and D = Enhancer lncRNA) and on their functions (A = Cis-acting lncRNA and $\mathrm{B}=$ (i) \& (ii) Trans-acting lncRNA).

1. Linear $\operatorname{lncRNAs}$ Linear lncRNAs are classified based on their genomic localization and interaction with protein-coding genes, presence of accompanying repeat elements, the likeness with mRNA as well as function. Based on their genomic location and their direction of transcription to complementary protein-coding genes, lncRNAs are classified into the following categories [50]:

(A) Intronic $\operatorname{lnc} R N A$

(i) Sense intronic lncRNAs are located inside the intron of the proteincoding gene and transcribed from a coding strand of the respective gene. For example, lncGHRL3:3 is believed to be an intronic and 
sense overlapping lncRNA. It is located at chromosome 3 within the ghrelin gene, probably involved in the regulation of T2DM, and can be presumed as a potential biomarker of T2DM [14].

(ii) Antisense intronic lncRNAs also exist in the intron region of a proteincoding gene but are transcribed from the opposite direction of the coding strand of that gene. For example, ANRASSF1 is an intronic antisense lncRNA that inhibits the function of the tumor suppressor gene RASSF1A by targeting its promoter region [51].

(B)

Intergenic $\ln \mathrm{R} N A$

(i) Sense intergenic lncRNAs are sited between two protein-coding genes with overlapping sense strands of the coding gene. LincRNA-p21 is an important example induced during DNA damage by p53 (a tumor suppressor protein) to relay its anti-oncogenic functions [52].

(ii) Antisense intergenic lncRNAs are located between two coding genes while transcribed from the antisense strand of a protein-coding gene, e.g., HOTAIR lncRNA. It belongs to a subclass of lincRNA that can decrease radiosensitivity in laryngeal cancer patients by regulating miR-454-3p [53].

(C) Exonic $\operatorname{lnc} R N A$

(i) Sense exonic lncRNAs are synthesized by transcribing lncRNA sequence from the sense strand of protein-coding gene and comprise the exons of that gene. For example, NONHSAG044354 is a sense exonic lncRNA associated with inflammatory bowel diseases gene BACH2 [54].

(ii) Antisense exonic lncRNA is produced if its transcript is derived from the intron of the protein-coding gene on the opposite strand, e.g., Tsix lncRNA. Tsix lncRNA is an anti-sense lncRNA to the Xist gene, known to orchestrate the $\mathrm{X}$-inactivation during dosage compensation by inhibiting the expression of Xist RNA and thus influences the random choice of which $X$ will be inactivated [55].

Enhancer RNAs (eRNAs)

Enhancer RNAs (eRNAs) originate from enhancer regions of coding genes and facilitate the positioning of transcription factors into the promoters of protein-coding genes [56]. PVT1 lncRNA is an eRNA transcribed from the PVT1 locus and has been proved to have an oncogenic function by regulating the MYC gene expression [57]. However, emerging studies pointed out that eRNAs are distinct from lncRNAs, although these species may share a similar role in activating mRNA transcription. They showed that unlike the promoters of lncRNAs, enhancers do not show any bias in the direction of transcription initiation. Moreover, lncRNAs go through splicing and polyadenylation maturation processes, while shorter eRNAs $(2 \mathrm{~kb})$ show little evidence of consistent splicing and polyadenylaion. eRNAs may facilitate activation of promoter-driven transcription or enhancer-promoter interaction $[58,59]$.

Based on the way they perform their regulatory function, lncRNAs are classified as: (A) Cis-acting $\operatorname{lnc} R N A$ s influencing the chromatin state or the expression of nearby genes, such as Kcnq1ot1 and the Xist lncRNAs which regulate gene expression in cis [60] or $(B)$ Trans-acting $\ln c R N A s$ leaving the transcription site and executing cellular functions in trans, i.e., on distant genes [61]. HOTAIR is one of the first reported lncRNAs which regulate gene expression in trans. It is expressed from the HOXC locus and repress the transcription from distant HOXD cluster by recruiting PRC2 [62]. Moreover, whether in a cis or trans way, lncRNAs bring out their gene regulatory activities either as signal lncRNAs, guide lncRNAs, decoy lncRNAs, or scaffold lncRNAs [63].

2. Circular IncRNAs (circRNAs) 
CircRNAs are recognized as lncRNAs that form a circle via back splicing of one or more exons named as extra-coding RNAs (ecRNAs), or one or more introns termed as circular intronic RNAs (ciRNAs), or both intron and exon fragments of the parent gene. Such circRNAs are more stable than linear ncRNAs since their circular structure is resistant to degradation by RNA decay machinery [64].

\subsection{Biogenesis}

Some lncRNAs or even classes of lncRNAs are regulated differentially during their biogenesis (as shown in Figure 2), as the biogenesis of lncRNAs is thought to be stagespecific and cell type-specific and controlled by stage and cell type-specific stimuli [65]. Different classes of lncRNAs are transcribed from either the exonic or intergenic area or the distant protein-coding areas of the genome, usually by RNA-polymerase II enzyme or RNA-polymerase III. Then, the pre-mature lncRNAs get capped at $5^{\prime}$-end with methylguanosine and $3^{\prime}$ - end polyadenylated [66]. Further, they undergo alternative splicing and RNA editing processes to generate diversity [67]. As a final point, mature lncRNAs are released and transported to other cellular sites based on their requirements in various cellular activities [68]. Epigenetic modification is involved in the biogenesis of lncRNAs; for instance, H3K4 methylation induces the transcriptional activation of the genes, while H3K27 tri-methylation directs gene silencing [69]. For the deep identification of functions and biogenesis of lncRNAs, various techniques including CLIP, RAP, CHART, ChIRP-Seq, RIP, CRISPR, and RNA pull-down are being used [70].

\section{LncRNAs and Regulatory Implications}

Characterization and analysis of functional pathways that the lncRNAs are involved with demonstrate that lncRNAs interact with the chromatin, with the RNA, or the protein to exhibit their effects to modulate migration, proliferation, differentiation, cell death, and apoptosis [71]. In general, they regulate gene expression in cancerous cells by either altering chromatin structure, activating or silencing a gene or a gene family, and in some cases, whole chromosomes via cis- or trans-methods [72]. Moreover, an essential regulatory aspect of lncRNAs is their association with the epigenetic machinery and the recruitment of its regulatory apparatus to specific loci, leading to the DNA methylation and/or posttranslational modifications of histones. Aberrant expression of such lncRNAs, which interact with epigenetic modifiers, leads to severe epigenetic disruption and thus altered gene expression, cellular dysregulation, and malignant transformation. For example, HOTAIR causes the BC cell invasion and metastasis by interacting with and causing genomic relocalization of PRC2 through $\mathrm{H} 3 \mathrm{~K} 27 \mathrm{me} 3$, leading to epigenetic silencing of the HOXD locus [73].

\section{LncRNAs and Diagnosis of Cancer}

Tracking the levels of lncRNAs present in the body fluids in cancerous patients can be an effective lncRNA-based diagnostic marker for such cancers. For example, lncRNA PCA3, released in the urine of prostate cancer patients, has been a sensitive and more specific marker for these patients than serum prostate-specific antigen testing, and it is also a convenient and less invasive procedure [71]. Similarly, lncRNAs, such as H19, TINCR, AOC4P, BANCR, LINC00857, and CCAT2, are detectable in body fluids and can be used to efficiently differentiate gastric cancer patients from healthy controls [71,74]. Thus, in the future, lncRNAs could be used as a very proficient and cost-effective diagnostic tool in clinical practice.

\section{LncRNAs and Therapy Resistance in Cancer}

Growing evidence suggests that lncRNAs are intimately involved in cancer therapy resistance via multiple modes of action. For example, upregulated expressions of NEAT1 and HOTAIR are responsible for therapeutic resistance in BC, OC, and various other cancer cells to chemotherapy, e.g., paclitaxel, 5-FU, cisplatin, tamoxifen, radio and endocrine 
therapies [75-78]. Similarly, H19, MIR2052HG, TINCR, DCST1-AS1, NONHSAT101069, and CASC2 are involved in fulvestrant, aromatase inhibitors, trastuzumab, doxorubicin, epirubicin, and paclitaxel resistance, respectively, in BC patients by way of different mechanisms [79]. The usual resistance mechanisms via lncRNAs to diverse therapeutic strategies may involve altered drug targets, increased drug efflux, maintenance of cancer stemness, immune response deregulation, and activated bypass signaling pathways. Thus, the indepth understanding of the association of lncRNAs in resistance to therapies may benefit the clinical outcome of patients. They can also be used as therapeutic targets to tackle therapy resistance in such cancers. For example, therapeutic delivery of locked nucleic acids targeting LINK-A lncRNA has been seen in a preclinical study to improve the BC sensitivity to immune checkpoint inhibitors [79]. On the contrary, some lncRNAs have been seen to suppress therapeutic resistance. For instance, lncRNA LINC00968 sensitizes $\mathrm{BC}$ cells to chemotherapeutics paclitaxel and adriamycin by targeting and silencing WNT2 and inhibiting the Wnt $2 / \beta$-catenin signaling pathway [80]. So, drug resistance suppressor lncRNAs can be used in combination with chemotherapeutics to enhance the effectiveness of such drugs.

\section{Current Clinical Applications of lncRNAs}

LncRNAs can be determined rapidly, efficiently, and cost-effectively in gastric juice, urine, blood serum, saliva, and tissues, making them exceedingly versatile analytes. Thus, considering the clinical need for more accurate predictive markers and early diagnosis of cancer patients, lncRNAs will be an efficient molecular tool that might aid in clinical management. Some lncRNAs have been approved by the U.S. Food and Drug Administration (FDA) as biomarkers for patients' clinical management, indicating their importance in the clinic. For instance, the most important example of lncRNA approved by the FDA for routine clinical practice is PCA3, used for PROGENSA PCA3 urine-based molecular diagnostic testing of prostate cancer. Similarly, many more lncRNAs are on the way to FDA approval and are going through different phases of clinical trials, e.g., the lncRNA H19 is at the stage of clinical trials for glioblastoma, ovarian, bladder, and pancreatic cancer. Moreover, HOTAIR, MALAT-1, and NRCP are under pre-clinical trials for EC, prostate cancer, and OC, respectively [81,82]. Hence, IncRNAs associated with clinicopathologic characteristics of various diseases, including cancers, become more advanced as prognostic and diagnostic markers and drug resistance suppressors.

\section{LncRNAs in Female-Oriented Cancers}

The IncRNA transcripts show diverse functions in various biological processes, as they are seen to be involved in more or less every step of the life cycle of genes [2]. However, the deregulations and aberrant expressions of lncRNAs are linked with the incidence of diverse diseases, including tumorigenesis in human beings [83]. LncRNAs influence the biological behaviors of various cancers by functioning either as tumor suppressor lncRNAs or oncogenic lncRNAs [84].

For instance, SNHG3 is a novel lncRNA that has been identified to have a tumorsuppressor function during papillary thyroid carcinoma (PTC) development, and its silencing can activate tumor progression by modifying the AKT/mTOR/ERK signaling pathway. The study involved 62 patients and observed a 1.5-fold decrease in SNHG3 expression in PTC tissues of 38/62 (61.3\%) patients [85]. Similarly, GAS5 works as a tumor suppressor lncRNA in HCC cells via GAS5/miR-182/ANGPTL1 axis [86]. On the contrary, a study conducted to determine the role of SNHG3 in breast cancer in a nude mouse model demonstrated that SNHG3 promotes cancer proliferation and metastasis by functioning as a miR-326 sponge [87]. The lncRNAs induce cancer invasion, proliferation, stemness, and metastasis by utilizing different mechanisms, i.e., by either promoting epithelial-to-mesenchymal transition (EMT) [88], regulating miRNAs expression profile via miRNAs sponging [89], modulating cell cycle including apoptotic pathways [90], interfering in mRNAs splicing [91], inducing resistance to different anti-cancer drugs [92], cellular 
metabolic reprogrammings [93], altering localization of proteins using direct binding [94], or regulating various associated metastatic signaling pathways [95].

Thus, it is likable to speculate that targeting the lncRNAs may help develop novel therapeutic strategies for cancers.

An increasing number of lncRNAs have been studied and found to be involved in cancers among females [96,97]. Several such lncRNAs involved in tumorigenesis or tumor suppression in female-oriented cancers are mentioned briefly in Figure 3. Different factors such as age, menopause status, and obesity are seen to be associated with increased cancer risks among females, and involvement of lncRNAs in such circumstances has been observed and studied by various researchers. For instance, $\mathrm{Xu}$ et al. observed in a casecontrol study involving $439 \mathrm{BC}$ patients along with 439 age-matched healthy controls that the rs3787016 TT genotype ( $p$-value 0.018 ) of SNP in lncRNAs is associated with the incidence of $\mathrm{BC}$ among females, especially with an enhanced risk among premenopausal females [98]. Similarly, a study presented evidence of a link between lncRNAs expression and the reproductive and obesity-related factors in the breast tissue of healthy women [99]. The same lncRNAs, LSINCT5 and GAS5, have also been extensively studied and found to be involved in breast tumors [100]. Cross-talk between lncRNAs and hormone signaling is also seen in cancer incidence among women. The ER signaling pathway promotes tumor progression and the cross-talk between such ER signaling pathway and cell cycle regulation, conducted by lncRNA MAFG-AS1 via MAFG-AS1/miR-339-5p/CDK2 axis, has also been identified in ER+ breast cancer cells, possibly promoting tamoxifen resistance [101]. In the following sections, we will review and highlight the characteristics and functions of some of the lncRNAs, i.e., HOTAIR, NEAT1, H19, MALAT1, and MEG3, frequently involved in several female-oriented cancers.

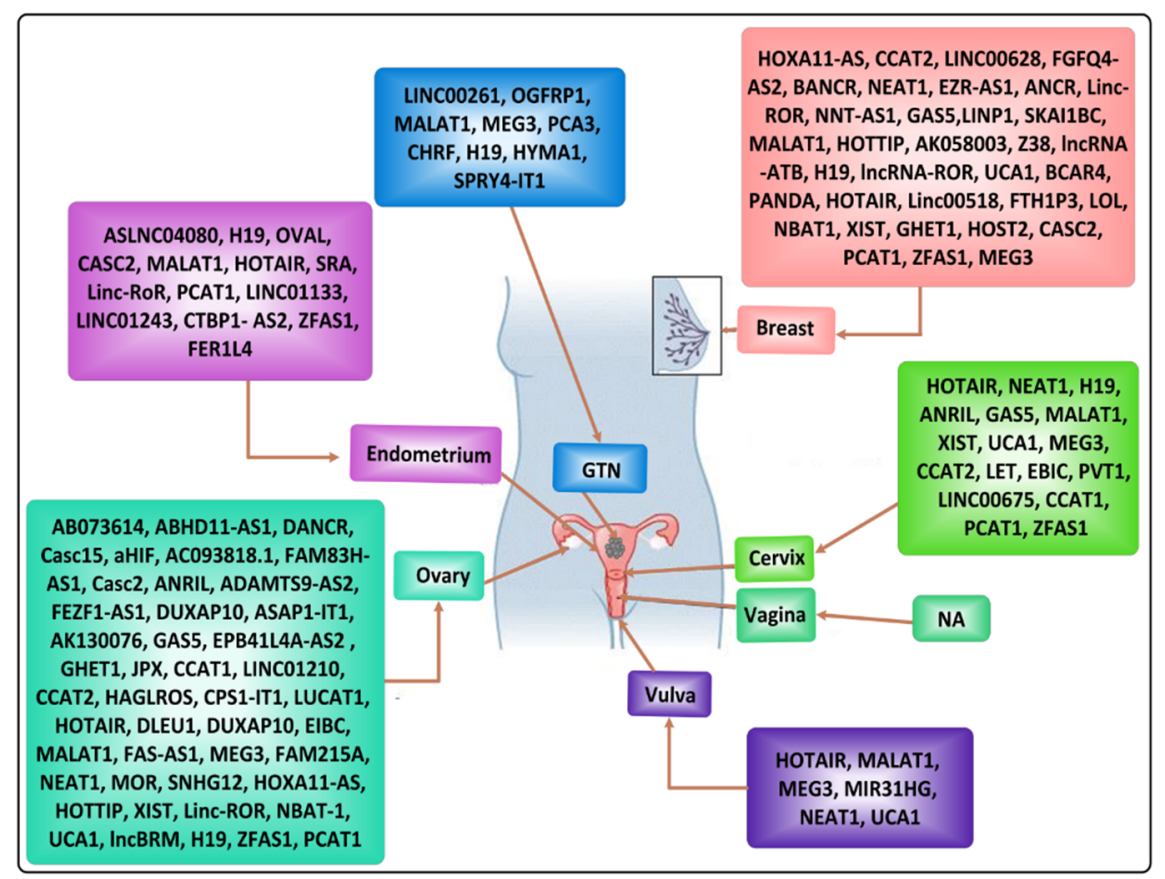

Figure 3. Most common lncRNAs associated with female-oriented cancers.

\subsection{HOTAIR}

HOX transcript antisense intergenic RNA (HOTAIR) is a trans-acting lncRNAs located between HOXC11 and HOXC12 genes on chromosome 12q13.13, with 2158 nucleotides long and consisting of six exons [102]. Early studies exposed the HOTAIR as a significant regulator of the chromatin status and a facilitator of transcriptional silencing. It can recruit PRC2 (polycomb repressive complex 2) and causes transcriptional repression by trimethylation of histone $\mathrm{H} 3$ lysine 27 (H3K27) complex in the HOXD locus, while at the $3^{\prime}$ end it can interact with LSD (the lysine-specific histone demethylase) complex of 
LSD1/CoREST/REST which also leads to gene silencing [103]. HOTAIR suppresses the expression of various tumor suppressor genes. It is overexpressed in a variety of primary and metastatic cancers, including female-oriented cancers (as shown in Figure 4) and several other cancers, such as hepatocellular carcinoma, pancreatic cancer, prostate cancer, lungs carcinoma, colorectal cancer, vulvar cancer, and esophageal squamous cell carcinoma (ESCC) $[104,105]$.

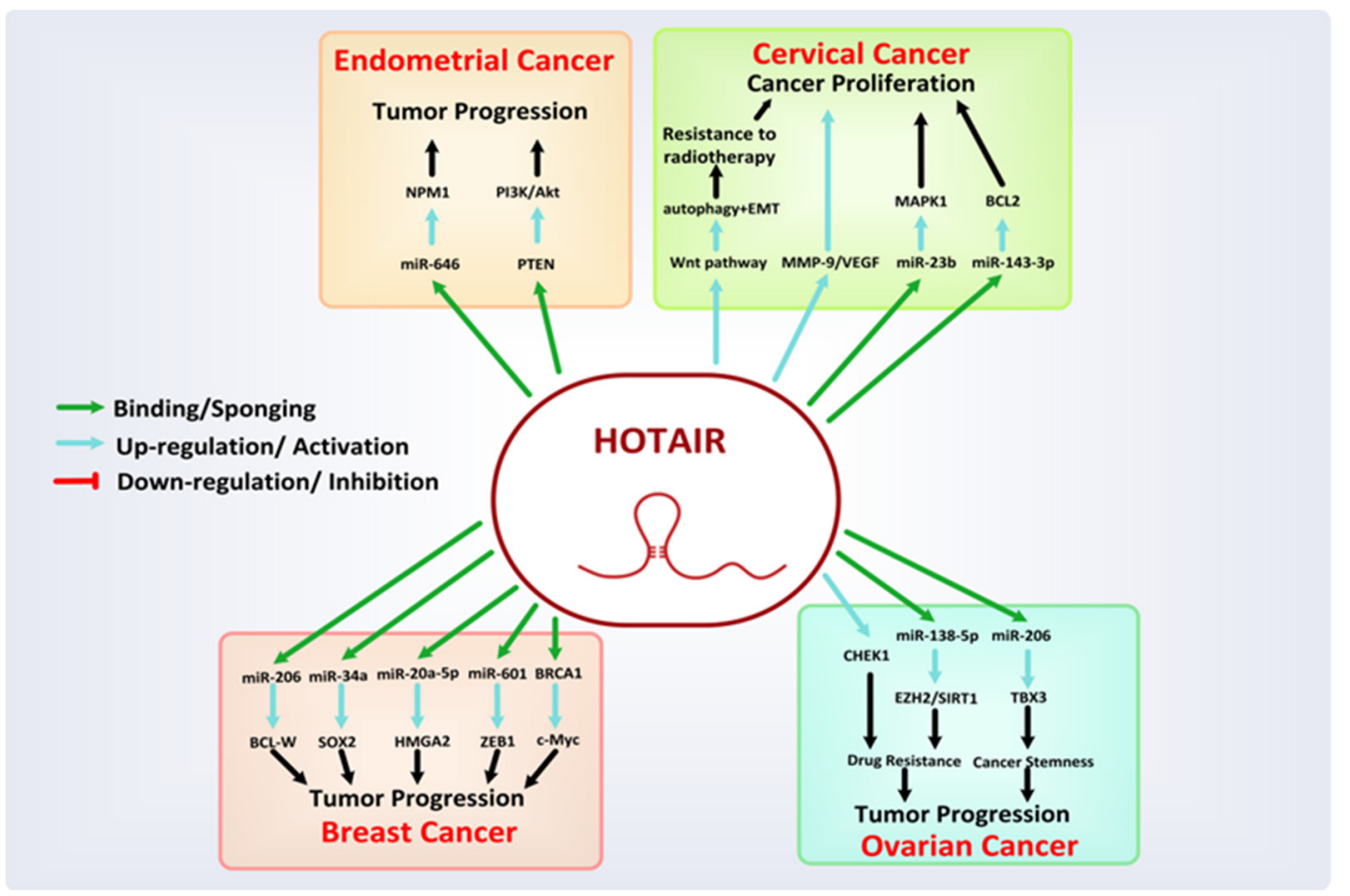

Figure 4. Mechanism associated with the oncogenic role of HOTAIR in female-oriented cancers.

In $\mathrm{BC}$, overexpressed HOTAIR plays a crucial role in tumor progression by directly or indirectly modulating several molecular pathways involved in growth, malignant proliferation, invasion, self-renewal, EMT, metastatic spread, and poor prognosis, including drug resistance. For instance, the elevation of HOTAIR expression in ER+ BC cells, regulated by estradiol (E2), leads to tumor formation [106]. Similarly, in a recent study that evaluated normal and BC tissues of 15 patients, HOTAIR has been reported to promote BC development and migration through upregulation of either BCL-W (an anti-apoptotic protein) via miR-206 sequestering $(p<0.001)$ [107], SOX2 via epigenetic suppression of miR-34a [53], HMGA2 via miR-20a-5p suppression [108], ZEB1 via miR-601 sponging [109], or by regulating a broad spectrum of various other miRNAs as well. Moreover, HOTAIR can mediate the oncogenic action of c-Myc, by competing with BRCA1 (a tumor suppressor gene) [103] and boost the cancerous cells resistance to radiotherapy and various targeted drug therapies like lapatinib and imatinib [110]. In gynecological cancers, HOTAIR aberrant expression has been involved in the oncogenic progression, lymph node metastases, and poor prognosis of EC [104]. In EC, HOTAIR gene expression is seen to be increased by E2 in 23 human EC tissues compared with normal tissues, which in turn upregulates the NPM1 expression by interacting with miR-646 in EC cells leading to the metastasis of EC cells [111]. Similarly, HOTAIR can promote EC proliferation by activating the PI3K/Akt signaling pathway by binding to PTEN [112]. Furthermore, downregulation of HOTAIR expression in EC leads to overcoming progesterone resistance via epigenetic regulation of progesterone receptor isoform B [113].

In CC, enhanced HOTAIR expression can lead to progressive tumor stages, lymphatic node and lymphatic vessel metastasis, adenocarcinoma, and poor prognosis. HOTAIR can increase the possibility of cervical cell tumor development, angiogenesis, and metastasis, e.g., by upregulating the expression of MMP-9, VEGF growth factors, or EMT-related 
genes $[77,114]$, targeting miRNAs like miR-23b/MAPK1 axis, or regulating the expression of BCL-2 by miR-143-3p sponging $[115,116]$.

In epithelial OC, overexpression of HOTAIR predicts elevated tumor metastasis and poor prognosis. The regulation of EMT-related genes and specific matrix metalloproteinases (MMPs) by HOTAIR is believed to be responsible for OC metastasis $[117,118]$. Moreover, the hyper-expression of HOTAIR is also co-related with specific miRNAs expressions [119]. For instance, HOTAIR upholds the OC stem cells stemness by upregulating a proteincoding gene TBX3 through the miR-206/TBX3 axis [120]. HOTAIR also causes paclitaxel and cisplatin resistance by increasing the CHEK1 protein level and sponging miR-138-5p to avoid its binding to SIRT1 and EZH2, respectively [78,121].

HOTAIR has also been investigated to be involved in the proliferation, invasion, apoptosis, and migration in VSCC [122].

\subsection{NEAT1}

Nuclear Enriched Abundant Transcript 1 (NEAT1) is a lncRNA located on chromosome 11q13.1 with having two isoform transcripts, 3.7 kb long NEAT1_1 and 23 kb long NEAT1_2, that differ in their $3^{\prime}$ UTR region processing [76]. NEAT1 is involved in the nuclear paraspeckle formation, where it associates with various paraspeckle proteins like PSPC1, p54nrb, and SFPQ. To form an RNA-protein complex, the long transcript NEAT1_2 interacts with SFPQ/PSF and p54nrb/NONO, followed by the recruitment of NEAT1_1 and PSPC1 to this complex [123]. NEAT1 epigenetically regulates the gene expression by either modifying gene transcription and translation via recruiting or sequestering TF to or from gene promoters, modulating RNA splicing and protein stabilization via associating with RBPs, or sponging miRNAs to vary the expression of their target RNAs. Studies have demonstrated the dysregulation of NEAT1 expression during the progression of cancer, where its expression is considerably linked to tumor size, distant metastasis, TNM stage, drug resistance, and patient survival [123-125].

NEAT1 is overexpressed in BC cells and closely associated with cancerous cell proliferation, advanced clinical stages, lymph node metastases, chemoresistance, and poor patient prognosis [126]. A recent study involving $106 \mathrm{BC}$ patients revealed that overexpressed NEAT1 $(p<0.05)$ in cancer patients as compared to healthy individuals facilitates the BC cell's proliferation and migration by regulating the expression level of RTCB and CBX7 genes, i.e., downregulation of RTCB and upregulation CBX7, probably by binding to DNA in the nucleus [127]. Moreover, NEAT1 has also been seen to induce chemoresistance [76]. It prompts cancer proliferation, EMT, and metastasis by interacting with miRNAs. For example, it can upregulate the expression of miR-21, which in turn upregulates the RRM2 expression level and BC propagation [128], or downregulate the expression of miR-146b-5p in BC cells [129].

In EC, the expression level of NEAT1 and some positively associated genes, LEF1, MMP9, and c-myc has been upregulated with downregulation of miRNA-146b-5p via the Wnt/ $\beta$-catenin signaling pathway, which can be regulated in vice versa by progesterone treatment therapy to suppress the EC [130]. Similarly, overexpressed NEAT1 has been investigated to drive the aggressive progression, invasion, migration, apoptotic suppression, and drug resistance in EC cells by facilitating TIMD4 expression via sponging miR-202$3 p$ [131], by regulating the miR-144-3p/EZH2 axis [132], and by elevating the expression of oncogene STAT3 and other TM related genes including ROCK1, MEF2D, VEGF-A, WNT7A, KPNA4, and PDE4B through sponging the tumor suppressor miR-361 [133].

The expression of NEAT1 has also been upregulated in CC cells and positively correlated with lymph node metastasis and the TNM stage. As such, overexpression of NEAT1 can accelerate the proliferation and migration of CC by regulating the miR-124/NF- $\mathrm{KB}$ pathway [134], by regulating the miR-889-3p/E2F7 axis via activation of the PI3K/AKT pathway [135], or by sponging various other miRNAs [136,137]. A recent study demonstrated that overexpressed NEAT1 could suppress the expression of miR-361, leading to 
the elevated levels of an EMT key activator HSP90 and consequently enhanced sphere formation and EMT in CC cells [138].

In OC, NEAT1 promotes cancer cell proliferation, invasion, migration, EMT, and angiogenesis by regulating the expression of a wide variety of miRNAs and associated pathways. For example, upregulation of the FGF9 pathway by sponging miR-365 [139], regulation of TJP3 expression by interacting with and sponging miR-1321 [140], alteration of cancer proliferation, apoptosis and colony formation by regulation of miR-4500/BZW1 axis [141], and by sponging many other miRNAs [142]. Moreover, in a study involving 18 cisplatin-sensitive and 19 cisplatin-resistant OC patients, overexpressed NEAT1 was reported to induce cisplatin resistance $(p=0.031)$ in OC cells via the regulation of miR-7705p and PARP1 [143].

Similarly, NEAT1 has been documented in the development and progression of VSCC [144]. A detailed model of the mechanisms involved in cancer progression by NEAT1 is presented in Figure 5.

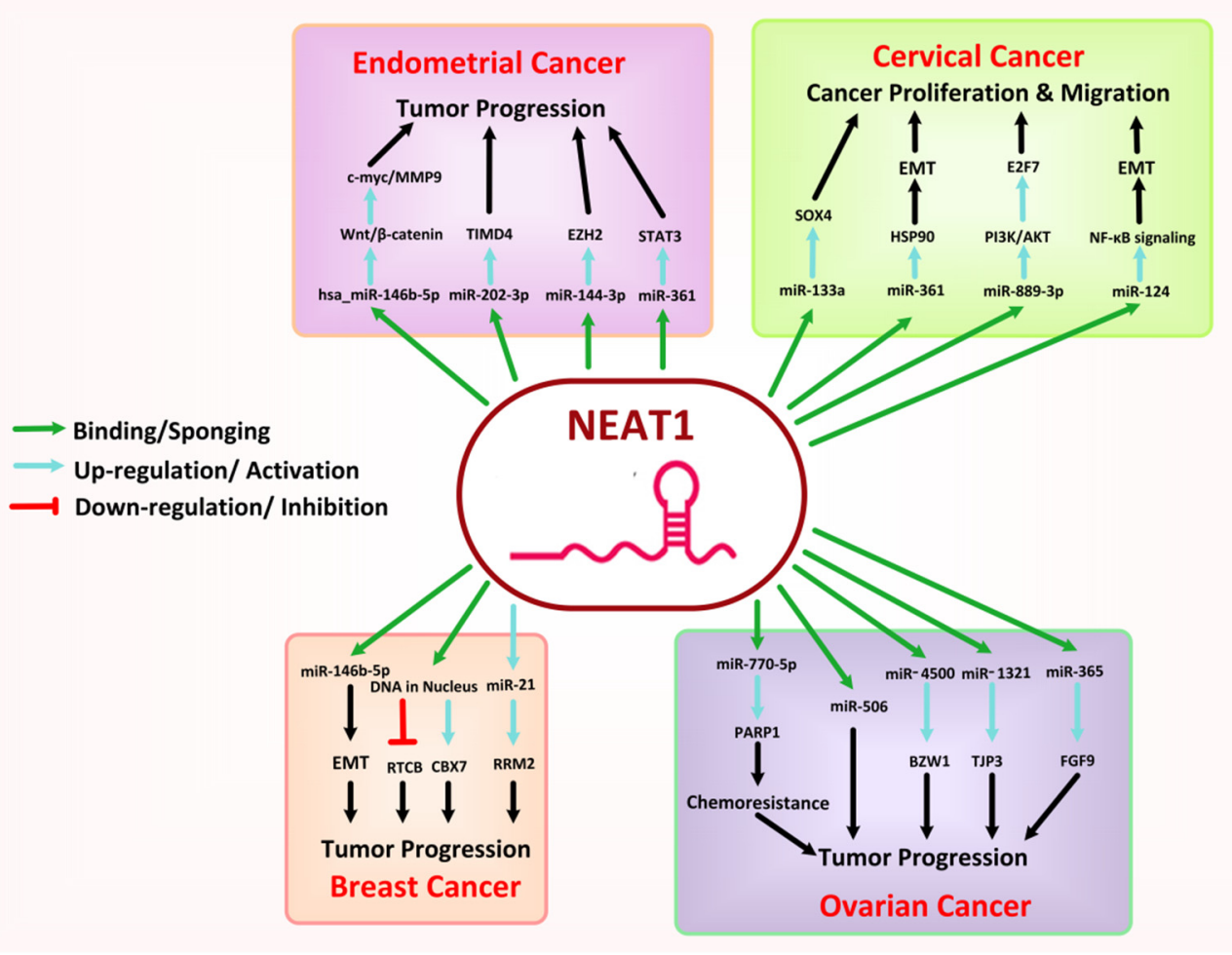

Figure 5. Mechanism associated with the oncogenic role of NEAT1 in female-oriented cancers.

\section{3. $H 19$}

The lncRNA H19 consists of a 2.3-kb long transcript and sites on the human gene cluster of H19/IGF2 on chromosome 11p15.5. It is encoded by the gene H19, one of the imprinting genes with maternal expression, fully capped, polyadenylated, spliced, and comprises five exons with four introns $[145,146]$. H19 is considered bi-functional RNA, as it works both as a lncRNA, a precursor for miR-675, and is involved in promoting normal biological processes like angiogenesis, inflammation, neurogenesis, apoptosis, and cell death [147]. It is an oncofetal lncRNA widely expressed in the embryo and downregulated at birth; however, it is replenished in different tumors. Furthermore, the H19 single nucleotide polymorphism (SNP), such as rs3741219, rs3024270, rs217727, rs2839698, rs2107425, and rs2735971 in various ethnic populations is seen to be associated with the susceptibility of multiple cancers like pancreatic cancer, colorectal cancer, lung cancer, OSCC, glioma, BC, and gynecological cancers [148-150]. However, there is always a debate about whether H19 works as an oncogenic factor or a tumor suppressor [151]. 
H19 regulates the gene expression by either recruitment of epigenetic RFs to the chromatin surface and regulating the gene expression by way of methylation or by regulating the two miRNAs (i.e., miR-675-3p and miR-675-5p), which are derived from exon 1 of H19 and in turn regulate the gene expression, or by interacting with and sponging several other miRNAs [152].

In BC, the aberrant expression of H19 is associated with the proliferation and progression of the tumor by diverse underlying molecular mechanisms, including interaction with c-myc, encoding microRNA-675, and competition for the regulation of endogenous RNAs [153,154]. 43 BC patients evaluated at Zhejiang University (Hangzhou, China) showed that the H19/let-7/Lin28 ceRNA pathway is involved in cellular proliferation, autophagy, and EMT in BC cells. Such H19/let-7/Lin28 loop inhibits autophagy and promotes EMT in breast cancer cells by exhibiting a significant positive relationship between H19 ( $p=0.0317)$ and Lin28 ( $p=0.0128)$ expression [155]. Furthermore, H19 has been observed to promote cancer cell invasion, EMT process, and lymph node metastases by enhancing the expression of its target gene TNFAIP8 via antagonizing tumor suppressor p53 [156].

In EC, the overexpressed lncRNA H19 promoted cancer cell proliferation considering fresh EC tissues of 43 cases from July 2010 to July 2012 via upregulating the expression of the HOXA10 gene by competitively targeting and downregulating miR-612 expression. It can also promote EC aggressiveness by modulating the EMT process $[157,158]$, although it is not expressed in the normal endometrial epithelium [157]. H19 binds to let-7 and downregulates its expression, leading to enhanced expression levels of let-7 targets (Imp3, c-myc, and HMGA2) and causing enhanced EC cell invasion and migration [159]. Moreover, Zhu et al. analyzed 56 pairs of CC and adjacent normal tissues collected from CC patients $(p<0.05)$ and showed the involvement of H19 in tumor formation of EC based on its ability to regulate the miR-20b-5p/AXL/HIF-1 $\alpha$ signaling pathway [160].

Downregulated H19 has been involved in CC proliferation, invasion, metastasis, and radioresistance [161]. In previous studies, loss of imprinting (LOI) of H19 has also been associated with the incidence of various diseases, including CC and EC [152,162]. Ou et al. reported the negative correlation between $\mathrm{H} 19$ and miR-138-5p expression in CC patients since downregulation of miR-138-5p expression promotes tumor development and proliferation via upregulation of its target SIRT1 [163].

In OC, H19 acts as an oncogenic lncRNA because overexpressed H19 causes the inhibition of OC cell's apoptosis by regulating specific apoptosis-related proteins [97]. Like in CC, LOI of H19 genes may also be involved in the proliferation of OC cells [164]. A study on TGF- $\beta$ induced EMT in OC cells demonstrated that H19 prompts such EMT process by competitively binding and sponging miR-370-3p because overexpressed miR-370-3p reasons the suppression of TGF- $\beta$-induced EMT in OC cells [165]. H19 has also been responsible for cisplatin resistance in OVCAR3 cells, and Sajadpoor et al. showed that the downregulation of $\mathrm{H} 19$ by valproic acid could endorse the cisplatin sensitivity and apoptosis in OC A2780 cells [166]. Moreover, polymorphisms in IGF2/H19 gene locus are presumably associated with platinum resistance in OC. Interestingly, the H19-rs4244809 GG genotype is seen to be associated with a reduced risk of platinum resistance, while rs3842761 and rs4244809 are connected with a significant risk of platinum resistance in FIGO stage III-IV [167].

Abnormal expression of $\mathrm{H} 19$ has also been linked with GTN, especially choriocarcinoma [168]. A study showed that downregulation or knockdown of H19 expression by lentiviral vectors expressing H19-specific siRNA obstructed the proliferation of human choriocarcinoma cell line JAR [169]. Furthermore, S. Yu et al. studied that H19 is also related to the chemo-resistance mechanisms in choriocarcinoma cells, and they found that, after knock out of H19 from JEG-3/5-FU and JEG-3/MTX cells, the drug resistance index was diminished, leading to significantly reduced cancer proliferation, invasion, and migration with simultaneously increased apoptosis [170]. For a hypothetical model on the role of H19, see Figure 6 below. 


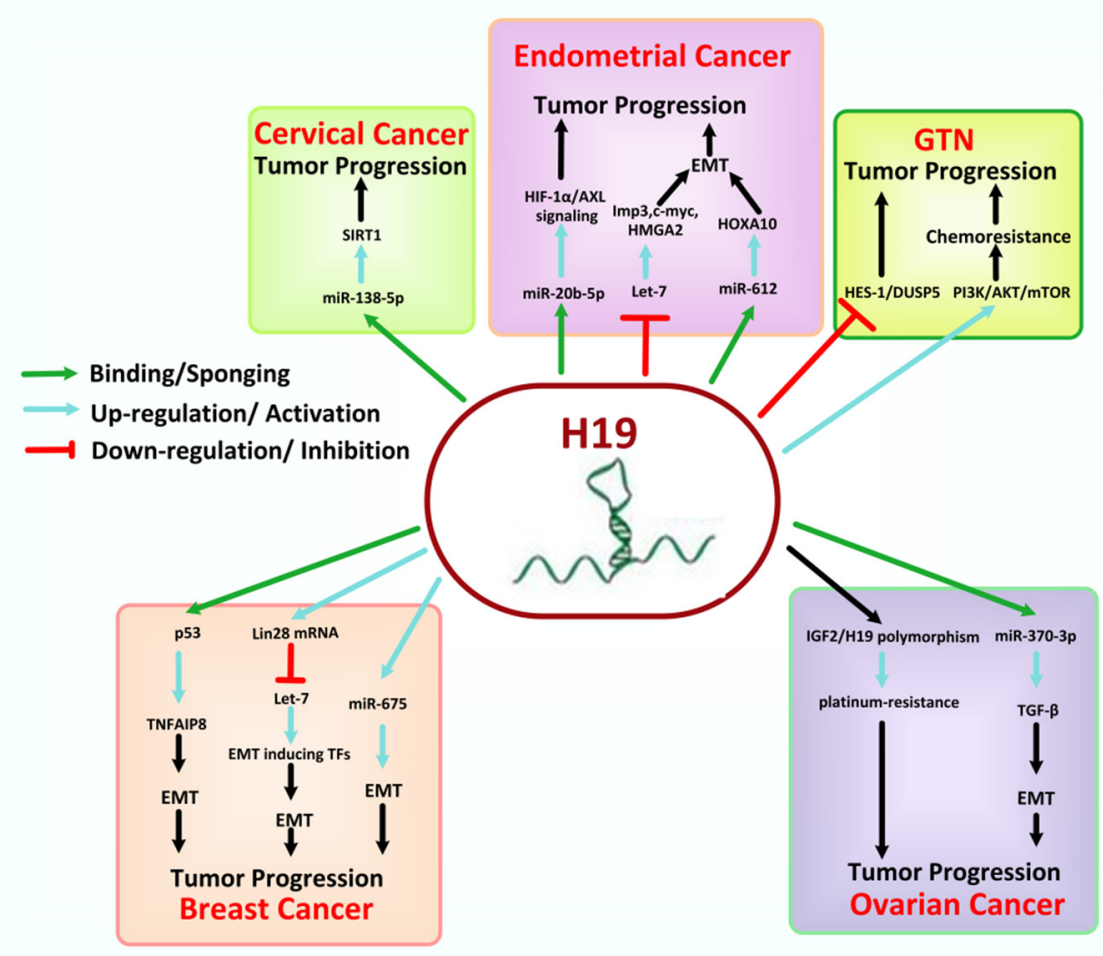

Figure 6. Mechanism associated with the oncogenic role of H19 in female-oriented cancers.

\subsection{MALAT1}

Metastasis Associated Lung Adenocarcinoma Transcript 1 (MALAT1), also known as NEAT2, is $\sim 8 \mathrm{knt}$ long in humans, with its gene located on chromosome 11q13.1. It is nuclear retained and highly conserved, exhibiting more than $80 \%$ conservation at the transcript's $3^{\prime}$ end [171]. It also displays an unusual $3^{\prime}$ end processing and significant evolutionary conserved secondary and tertiary structural features [172]. It is richly expressed in tissues and cells and regulates gene expression in a context-dependent manner, both at the transcriptional and post-transcriptional levels [173]. Accumulated evidence confirmed that it shows a low protein-coding potential by two independent coding potential calculating algorithms, i.e., CPAT and CPC2 [174]. Moreover, MALAT1 is localized at nuclear speckles being enriched at the periphery, although it is not involved in nuclear speckles formation [175].

It has been evidenced to regulate gene transcription, directly or indirectly, either by binding with histone modification enzymes or transcription factors. Post-transcriptionally, it regulates the mRNAs and protein expression by competitively binding miRNAs and acting as a sponge to sequester miRNAs [176-179]. MALAT1 has been seen to be associated with different diseases, including cancer. Initially, its elevated expression was identified in primary lung cancer cells with a high tendency of metastasis [180]. Since that overexpressed MALAT1 has been reported to be linked with a wide variety of lymphoid or solid tumors with high tumor progression and metastasis propensity and 1.5-10 fold relative upregulation based on type and stage of cancer [172,181-184]. Moreover, single nucleotide polymorphism in MALAT1, e.g., rs619586 A > G polymorphism, has also been witnessed to be linked with elevated cancer risks [185]. On the contrary, some recent studies have postulated the downregulated expression of MALAT1 in human breast and colorectal cancer, where its decreased expression is associated with lessened patient survival [176,186].

In BC patients, MALAT1 is considered a possible indicator for early prognosis and diagnosis, as its expression is seen to be upregulated in such patients with downregulation of its expression in patients receiving breast-conserving surgery in combination with chemotherapy $[187,188]$. Stone et al. postulated that hypoxia in BC cells could also mediate 
the upregulation of MALAT1 by chromatin looping [173]. Such overexpressed MALAT1 can promote $\mathrm{BC}$ proliferation and progression by repressing various RNA molecules. For example, it can competitively bind with miR-1 and thereby affect the expression of CDC42 [189], downregulate hsa-miR-448, lead to aberrant expression of KDM5B [190], and regulate the expression of miR-143-3p and its putative target, RALGAPA2 [191]. Huang et al. detected the MALAT1 expression levels in tissue samples collected from $20 \mathrm{BC}$ patients and 20 healthy controls and found significantly higher expression levels in the former collective $(p<0.05)$. They concluded that this increased expression level of MALAT1 also induces angiogenesis in BC cells by downregulating the expression of miR-145 and upregulating VEGF expression [192]. Furthermore, MALAT1 can interact with numerous pathway target genes closely linked with tumor proliferation and metastasis. MALAT1 has expedited a pro-metastatic state in BC by trans-regulating the EEF1A1 epigenetic pathway after binding to its promoter regulatory element [193]. It can promote the invasion and proliferation of BC cells by regulating the XBP1-HIF- $1 \alpha$ pathway and HER-2 pathway in MDA-MB-23 and MDA-MD-435 cell lines, respectively [194], and assist in promoting trastuzumab resistance in HER2 overexpressing BC cells via FOXO1 and PI3/Akt pathway [195].

Studies have shown that MALAT1 can promote the proliferation, invasion, and metastasis of EC cells [196] with MALAT1 gene SNP, such as rs664589C > G polymorphism reported to considerably increase the risk of EC in females [197]. MALAT1 can repress the expression and function of miR-200c by competitively binding and sponging it and thus regulating the function of TGF $\beta$ in EC cells [198]. The PCDH10-Wnt/b-catenin-MALAT1 regulatory axis has also been involved in the development and proliferation of EC, in vivo and in vitro [199]. Moreover, Y. Shen et al. established that on the treatment of EC cell lines with MEK inhibitor RG7420, MALAT1 can decrease up to 6.13 times with upregulation of tumor suppressor miR-129-5p and downregulation of TAK1, leading to decreased metastasis and increased apoptosis of EC cells [200].

In CC, the expression of MALAT1 is known to be significantly augmented in cancer cells and tissues [172], most probably by IL-6/STAT3 and HPV18 E6/E7 mediated signaling pathways [184]. MALAT1 is seen to be structurally upregulated in CC cells. A recent study demonstrated that it undergoes 18 different structural rearrangements in CC-derived HeLa cells leading to the effect of more than 50 validated miRNA-binding sites by such putative secondary structure [201]. Thus, it prompts cancer proliferation and EMT in CC cells, for example, by sponging of miR-145, which was previously reported to suppress the tumor progression in CC cells by the regulation of Cyclin D1and CDKs [202], sponging of miR-202-3p and leading to upregulation of periostin expression [203], and sponging of miR-429 [204]. Furthermore, by sponging miR-625-5p, overexpressed MALAT1 has been characterized to weaken the inhibitory effect of miR-625-5p on NF- $\mathrm{KB}$ signaling in CC cell growth [205]. MALAT1 also promotes chemoresistance in CC patients, e.g., induction of cisplatin resistance by regulating BRWD1 and PI3K/AKT pathway [206].

$X$. Wu et al. have shown the involvement of MALAT1 in OC cell's stemness, nonadherent spheres formation, and cisplatin resistance via enhancing YAP expression and activity by inhibition of its nuclear-cytoplasm translocation [207]. Likewise, Bai et al. indicated the association of $A B C C 1$ and Notch1 signaling pathway for cisplatin resistance in OC because of MALAT1 by experimenting with 20 paired tumor tissue samples taken from OC patients and adjacent normal tissue samples [208]. By negatively regulating the expression of miR-143-3p and miR-503-5p via sponge-like action, MALAT1 promotes progression and proliferation of OC through activation of CMPK and JAK2-STAT3 pathways, respectively $[209,210]$. Moreover, it also functions as an oncogenic lncRNA by sponging miR-200c in OC cells [182]. MALAT1 facilitates the metastasis of OC by promoting RBFOX2mediated alternative splicing and EMT and regulating the expression of pro-apoptotic tumor suppressor gene KIF1B [211]. Similarly, a study involving sixty OC patients as well as OC cell lines with a $p$-value of $p<0.05$ showed that the overexpression of MALAT1 prompts cell proliferation, metastasis, and cell cycle progression in the $S$ phase with inhi- 
bition of cell apoptosis via activation of $\beta$-catenin, DVL2, cyclin D1, and Wnt/ $\beta$-catenin signaling pathway in OC cells with decreased expression of GSK-3 $\beta$ [212].

MALAT1 may also represent a possible diagnostic biomarker for VSCCs and choriocarcinoma $[213,214]$, but the studies about their incidence mechanisms are limited. However, Shi et al. showed that MALAT1 could promote choriocarcinoma tumor growth via regulation of miR-218-mediated Fbxw8 [215]. The detailed role of MALAT1 in female-oriented cancers is modeled below in Figure 7.

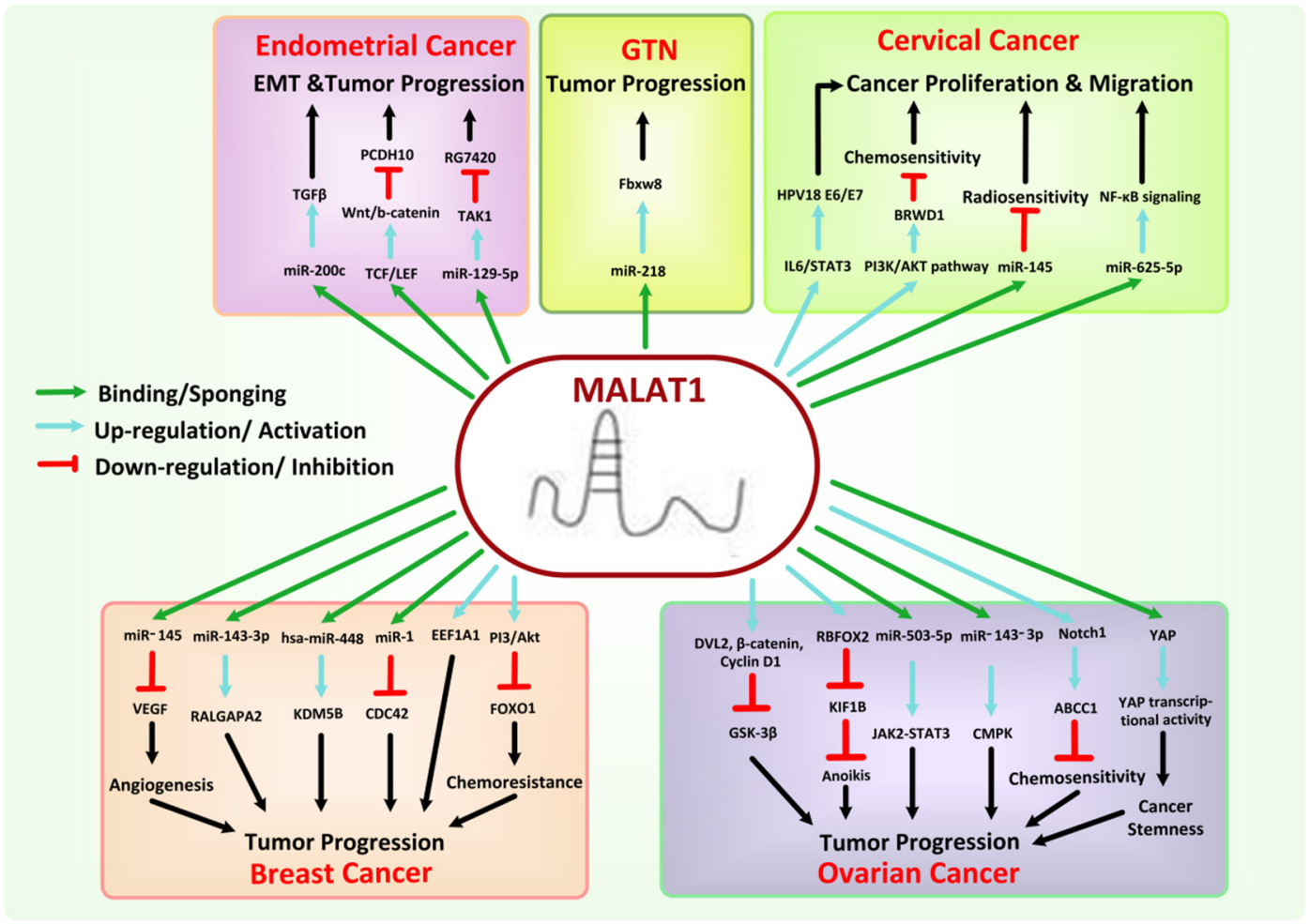

Figure 7. Mechanism associated with the oncogenic role of MALAT1 in female-oriented cancers.

\subsection{MEG3}

A maternally Expressed Gene 3 (MEG3) is a lncRNA encoded by the MEG3 gene and is $1.6 \mathrm{~kb}$ long. It is located in human chromosome 14q32.3, inside the imprinted DLK1MEG3 locus. The MEG3 gene is a maternally imprinted gene, is $35 \mathrm{~kb}$ long, and contains ten exons. Multiple factors are associated with the regulation of MEG3 gene expression, including cyclic adenosine monophosphate, DNA methyltransferase family, and nuclear factor- $\mathrm{KB}$ (NF-KB) [216,217]. MEG3 localizes both in the cytoplasm and nucleus [218] and is abundantly expressed in many tissues where it plays a prominent role in development and growth. At the same time, the loss of imprinting of MEG3 may lead to moderate to severe developmental disorders [219]. Moreover, SNP within the MEG3 intron may increase, among others, the susceptibility of breast cancer, oral squamous cell carcinoma, and type 1 diabetes [220-222]. The expression of MEG3 is downregulated in numerous human primary cancers or cancer cell lines where it functions as an antitumor component or a tumor suppressor, such as glioma, liver, breast, cervical, lung, ovarian, osteosarcoma, colorectal, bladder, prostate, and gastric cancer cells [223]. Thus, restoring the MEG3 expression can inhibit the cancer cell's proliferation and prompt their apoptosis [224]. MEG3 might function by regulating the foremost tumor suppressor genes p53 and Rb, controlling miRNAs, or inhibiting angiogenesis-related factors. However, dysregulation of MEG3 expression may lead to the development and proliferation of cancer, suggesting a potential biomarker and therapeutic target in human cancers $[223,225]$. 
In BC cells, MEG3 inhibits cellular proliferation and induces apoptosis by activating the endoplasmic reticulum stress or inducing p53 activation via the NF- $\mathrm{kB}$ signaling pathway [226]. The SNP, such as GG of MEG3 rs3087918, has also been associated with a decreased risk of BC, while MEG3 haplotype TCG possibly increases the risk of BC initiation [225]. Bayarmaa et al. postulated that MEG3 polymorphism seems to be associated with chemotherapy response and toxicity of cisplatin and paclitaxel in BC patients [227]. Moreover, Mingzhi Zhu et al. recruited 31 BC patients $(p<0.05)$ and found that MEG3 suppresses $\mathrm{BC}$ cells growth, migration, and invasion and induces paclitaxel resistance as well as cancer cells apoptosis via modulating the expression of miR-4513 and PBLD [228]. However, Ali et al. showed that MEG3 rs7158663 is associated with increased cancer susceptibility, even with higher TNM staging and tumor size $>5 \mathrm{~cm}$, via altering its gene expression level [229] and hyper-methylated MEG3 induces chemoresistance in BC cells [230].

Overexpressed MEG3 significantly reduces cancer proliferation and metastasis and can induce apoptosis of EC cells [159] either by regulating the Notch1 signaling pathway [231,232] or by downregulating the expression of PI3K protein and its downstream genes, including BCL-XL, VEGF-A, P70S6K, and Mtor [233]. Furthermore, Xu et al. evaluated a total of 65 human EC tissues and 18 normal samples and showed that MEG3 downregulates the miR-216a expression, leading to increased expression of tumor suppressor PD-L1. Thus, it inhibits the EC cell migration and invasion [234].

In CC cells, MEG3 serves as a prognostic indicator and diagnostic marker, and its expression is seen to be associated with HR-HPV infection, lymph node metastasis, tumor size, and FIGO staging [235]. At the same time, overexpressed MEG3 shows the potential to inhibit cancerous cells proliferation and induce apoptosis [236]. It has also been shown to suppress CC cells growth by downregulation of miR-21-5p levels in CC cell lines, by upregulation of the expression of SCT1 glycoprotein by sponging miR-7-5p, leading to the endoplasmic reticulum (ER) stress-mediated apoptosis of CC cells, or by ubiquitination of P-STAT3 [237-239]. Moreover, a recent study showed that lidocaine could inhibit the proliferation of CC by increasing the expression of MEG3 in HeLa cells. Such overexpressed MEG3 downregulates the expression of miR-421, leading to upregulation of BTG1 expression, which is negatively correlated with the expression of miR-421 [240].

The decreased expression of MEG3 is also considered a hallmark for tumor progression in OC [241]. J. Wang et al. showed that MEG3 inhibits cancer cell proliferation and induces apoptosis by regulating the expression of downstream tumor suppressor gene PTEN in OC [242]. Likewise, the overexpressed MEG3 inhibits cell proliferation and EMT in OC cells by sponging miR-205-5p via regulation of miR-219a-5p/EGFR axis and by regulating the expression of LAMA4 via miR-30e-3p sponging [243-245]. However, a recent study demonstrated that anisomycin inhibited proliferation, invasion, and angiogenesis in OC cells via inhibition of the Notch1 pathway by attenuating the molecular sponge effect of the MEG3/miR-421/PDGFRA axis [246].

MEG3 also represses the proliferation, migration, invasion and induces apoptosis of BeWo and JEG-3 of human choriocarcinoma cells through upregulating miR-211, leading to inhibition of PI3K/AKT and AMPK pathways [247]. Moreover, a multidrug resistancereversing agent, Schisandrin $\mathrm{A}$, has been reported to repress the tumor growth in choriocarcinoma cells by upregulating MEG3 expression and downregulating PI3K/AKT/NF- $\mathrm{kB}$ signal cascade [248]. We summarized the detailed response of MEG3 to female-oriented cancers in Figure 8. 


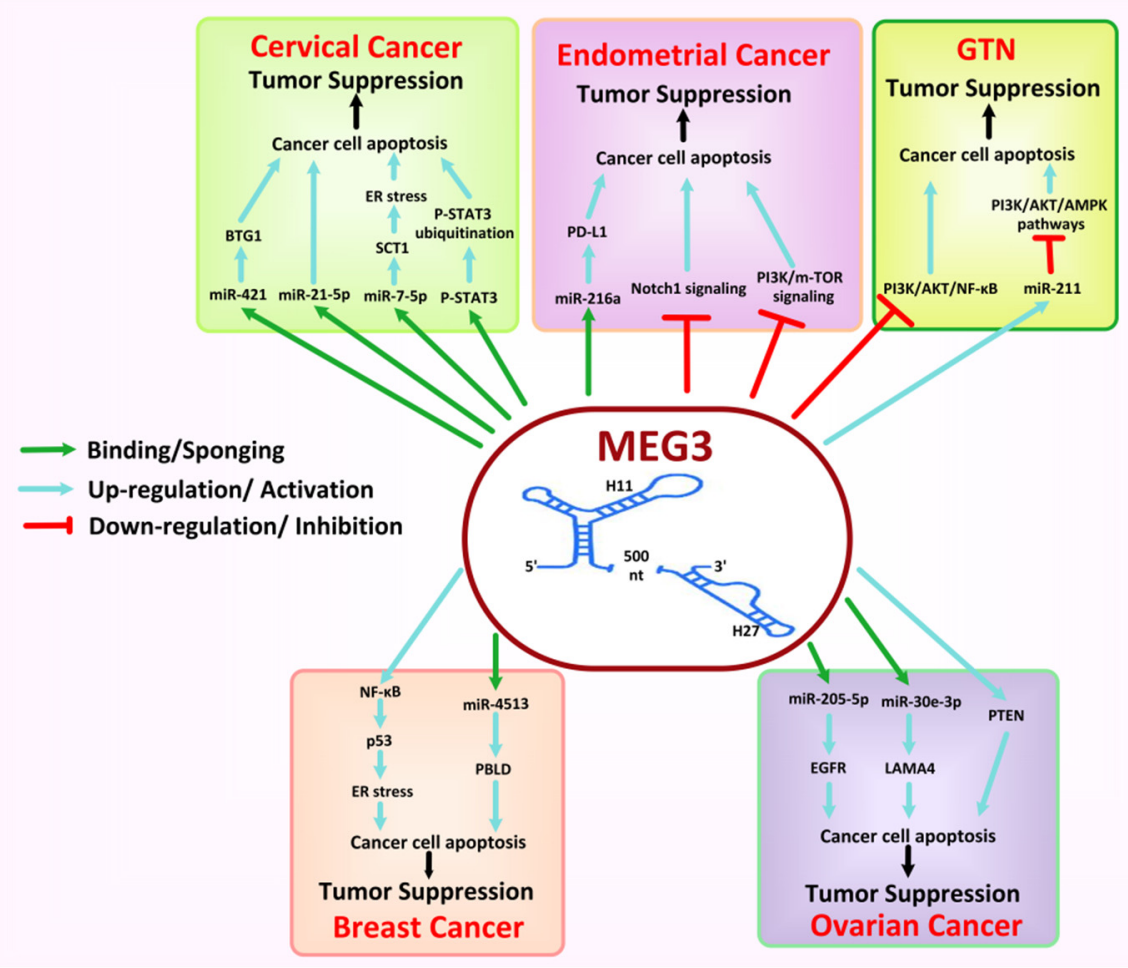

Figure 8. Mechanisms associated with the tumor suppressor of MEG3 in female-oriented cancers.

Several LncRNAs involved in proliferation, invasion, apoptosis, migration, metastasis, and drug resistance in female-orieted cancers are briefly discussed in Tables 1-6.

Table 1. LncRNAs involved in proliferation, invasion, apoptosis, migration, metastasis, and drug resistance in breast cancers.

\begin{tabular}{|c|c|c|c|c|}
\hline LncRNAs & Locus & Status & Target/Function & References \\
\hline HOXA11-AS & $7 \mathrm{p} 15.2$ & Oncogenic & EMT process & {$[22]$} \\
\hline CCAT2 & $8 \mathrm{q} 24.21$ & Oncogenic & OCT4-PG1, Wnt/B-catenin, Notch signaling pathway & [249] \\
\hline HOTTIP & $7 \mathrm{p} 15.2$ & Oncogenic & $\begin{array}{l}\text { miR-615-3p/HMGB3, E-cadherin, N-cadherin, Snail, } \\
\text { twist, PI3K/AKT, Wnt/ } \beta \text {-catenin pathway }\end{array}$ & [250] \\
\hline NEAT1 & $11 \mathrm{q} 13.1$ & Oncogenic & $\begin{array}{l}\text { RTCB, CBX7, EMT process, miR-21/RRM2, } \\
\text { miR-146b-5p }\end{array}$ & {$[128,129]$} \\
\hline LUCAT1 & $5 q 14.3$ & Oncogenic & miR-5702, miR-7-5p, SOX2 & [251] \\
\hline Linc-ROR & $18 \mathrm{q} 21.31$ & Oncogenic & EMT process via miR-205 & [96] \\
\hline $\operatorname{lncRNA-ATB}$ & chr 13, & Oncogenic & EMT process via targeting miR-141-3p & [252] \\
\hline LINP1 & $10 \mathrm{p} 14$ & Oncogenic & EMT process by anti-metastatic effects of P53 & [96] \\
\hline Z38 & $3 q 12.1$ & Oncogenic & $\mathrm{N} / \mathrm{A}$, silencing promotes apoptosis in breast cancer & [253] \\
\hline SKAI1BC & - & Oncogenic & KAI1/CD82 metastasis suppressor gene & [96] \\
\hline NNT-AS1 & $5 p 12$ & Oncogenic & miR-142-3p/ZEB1 axis & [254] \\
\hline AK058003 & $10 \mathrm{q} 22$ & Oncogenic & gamma-synuclein gene (SNCG) & [253] \\
\hline LINC00628 & $1 \mathrm{q} 32.1$ & Tumor suppressor & BCL-2/BAX/Caspase-3 signaling pathway & [255] \\
\hline ANCR & $4 q 12$ & Tumor suppressor & EMT via $\mathrm{E} 2 \mathrm{H} 2$ & {$[96,256]$} \\
\hline MALAT1 & 11q13.1 & Oncogenic & $\begin{array}{l}\text { miR-1/CDC42, miR-143-3p/RALGAPA2, EEF1A1, } \\
\text { XBP1-HIF-1 } \alpha \text {, HER-2 pathway }\end{array}$ & {$[191,193,194]$} \\
\hline GAS5 & $1 \mathrm{q} 25.1$ & Tumor suppressor & miR-23a, PTEN, miR-21 & {$[257,258]$} \\
\hline BANCR & $9 q 21.11$ & Oncogenic & MMPs, EMT, BAX, Caspase 3, PARP & [96] \\
\hline H19 & $11 \mathrm{p} 15.5$ & Oncogenic & c-myc, miR-675, Let-7/Lin28, EMT via TNFAIP8/p53 & {$[155,156]$} \\
\hline UCA1 & $19 \mathrm{p} 13.12$ & Oncogenic & $\begin{array}{l}\text { SATB1, ARID1A/CEBP } \alpha \text {, EMT by TGF- } \beta \text {, p27 (Kip1), } \\
\text { miR-122-5p, Wnt } / \beta \text {-catenin pathway }\end{array}$ & [259] \\
\hline BCAR4 & $16 \mathrm{p} 13.13$ & Oncogenic & $\begin{array}{l}\text { Wnt/ } \beta \text {-catenin, YAP/Hh signaling pathways, ERBB2, } \\
\text { EMT via mTOR signaling }\end{array}$ & [260] \\
\hline
\end{tabular}


Table 1. Cont

\begin{tabular}{|c|c|c|c|c|}
\hline LncRNAs & Locus & Status & Target/Function & References \\
\hline HOTAIR & $12 \mathrm{q} 13.13$ & Oncogenic & $\begin{array}{l}\text { miR-206/BCL-W, miR-34a/SOX2, } \\
\text { c-Myc/BRCA1,many othr miRNA }\end{array}$ & {$[53,103,107]$} \\
\hline FAM83H-AS1 & $8 \mathrm{q} 24.3$ & Oncogenic & miR-136-5p/MTDH axis & [261] \\
\hline NBAT1 & $6 \mathrm{p} 22.3$ & Tumor suppressor & DKK1, EZH2, PRC2 & [255] \\
\hline XIST & Xq13 & Tumor suppressor & miR-155/CDX1 axis, c-Met pathway & [255] \\
\hline GHET1 & $7 q 36.1$ & Oncogenic & N-cadherin, Vimentin, E-cadherin & [255] \\
\hline PCAT1 & $8 \mathrm{q} 24$ & Oncogenic & HIF-1a/RACK1 pathway & [262] \\
\hline ZFAS1 & $20 q 13.13$ & Oncogenic & $\begin{array}{c}\text { miR-589, MMP9, MMP2, BCL-2, Caspase-3, PTEN, } \\
\text { BAX, N-cadherin, E-cadherin, Vimentin PI3K/AKT } \\
\text { pathway }\end{array}$ & [263] \\
\hline HOST2 & $10 q 23.1$ & Oncogenic & miR Let-7b pathway & {$[255,264]$} \\
\hline CASC2 & $10 q 26$ & Tumor suppressor & miR-96-5p/SYVN1 pathway & [255] \\
\hline MEG3 & $14 \mathrm{q} 32.3$ & Tumor suppressor & NF-Kb/p53 pathway, miR-4513/PBLD & {$[226,228]$} \\
\hline
\end{tabular}

Table 2. LncRNAs involved in proliferation, invasion, apoptosis, migration, metastasis, and drug resistance in endometrial cancers.

\begin{tabular}{|c|c|c|c|c|}
\hline LncRNAs & Locus & Status & Target/Function & References \\
\hline HOTTIP & $7 \mathrm{p} 15.2$ & Oncogenic & PI3K/AKT pathway & [250] \\
\hline NEAT1 & 11q13.1 & Oncogenic & $\begin{array}{c}\text { Wnt } / \beta \text {-catenin signaling, miR-202-3p/TIMD4, } \\
\text { miR-144-3p/EZH2, miR-361/STAT3 }\end{array}$ & {$[130,131,133]$} \\
\hline ASlnc04080 & - & Oncogenic & Unknown & [265] \\
\hline H19 & $11 \mathrm{p} 15.5$ & Oncogenic & $\begin{array}{l}\text { EMT via Let-7 targets Imp3, c-myc, HMGA2, } \\
\text { miR-20b-5p/AXL/HIF-1 } \alpha\end{array}$ & {$[159,160]$} \\
\hline HOXB-AS1 & & Oncogenic & miR-149-3p/Wnt10b, c-Myc, $\beta$-catenin, cyclinD1 & [266] \\
\hline BANCR & $9 q 21.11$ & Oncogenic & MMP1/2, MAPK, MEK/ERK signaling & [159] \\
\hline UCA1 & $19 \mathrm{p} 13.12$ & Oncogenic & AMOTp130, YAP, Hippo-YAP, miR-143, FOSL2 & [267] \\
\hline PCGEM1 & $2 q 32$ & Oncogenic & miR-129/STAT3 & [268] \\
\hline MALAT1 & $11 q 13.1$ & Oncogenic & $\begin{array}{c}\text { miR-200c/TGF } \beta, \text { PCDH10-Wnt/b-catenin axis, } \\
\text { RG7420, miR-129-5p/TAK1 }\end{array}$ & [198-200] \\
\hline MEG3 & $14 \mathrm{q} 32.3$ & Tumor suppressor & Notch1, PI3K, BCL-XL, VEGF-A, P70S6K, mTOR & {$[231,233]$} \\
\hline HOTAIR & $12 q 13.13$ & Oncogenic & miR-646/NPM1, PTEN, PI3K/Akt signaling & {$[111,112]$} \\
\hline CCAT2 & $8 \mathrm{q} 24.21$ & Oncogenic & miR-216b/PI3K/AKT pathway, BCL-2 & [265] \\
\hline SRA & $5 q 31.3$ & Oncogenic & Wnt $/ \beta$-catenin, EIF4E-BP1 & [265] \\
\hline Linc-RoR & $18 \mathrm{q} 21.31$ & Oncogenic & miR-145, PI3K-Akt pathway & [269] \\
\hline PCAT1 & $8 \mathrm{q} 24$ & Oncogenic & BCL-2, vimentin, $\mathrm{N}$-cadherin, E-cadherin & [270] \\
\hline DLEU1 & $13 q 14.3$ & Oncogenic & $\begin{array}{c}\text { miR-490, BAX, N-cadherin, E-cadherin, Snail, CASP-3, } \\
\text { vimentin, SP1, PI3K, mTOR, AKT1, p70S6K, GSK3B, } \\
\text { STAT3, BCL-2, BCL-xl, }\end{array}$ & [265] \\
\hline TUG1 & $22 \mathrm{q} 12.2$ & Oncogenic & VEGF-A, miR-34a, miR-299 & [159] \\
\hline DCST1-AS1 & 1 & Oncogenic & miR-92a-3p/Notch1 & [271] \\
\hline ZFAS1 & $20 \mathrm{q} \overline{13} .13$ & Oncogenic & CDK4, Cyclin-D1, Ecadherin, Ncadherin, EMT & [263] \\
\hline GAS5 & $1 \mathrm{q} 25.1$ & Tumor suppressor & P27/PTEN, miR-103/PTEN, miR-222-3p & [272] \\
\hline FER1L4 & Chr. 20 & Tumor suppressor & PTEN, AKT & [159] \\
\hline SNHG8 & Chr. 4 & Oncogenic & miR-152/c-MET & [265] \\
\hline
\end{tabular}

Table 3. LncRNAs involved in proliferation, invasion, apoptosis, migration, metastasis, and drug resistance in cervical cancers.

\begin{tabular}{ccccc}
\hline LncRNAs & Locus & Status & Target/Function & References \\
\hline HOTAIR & $12 \mathrm{q} 13.13$ & Oncogenic & MMP-9, VEGF, EMT-related genes, miR-23b/MAPK1, & [77,114-116] \\
mNT-AS1 & $5 \mathrm{p} 12$ & Oncogenic & Wnt/ $\beta$-catenin pathway, miR-186/HMGB1 axis & [254] \\
ANRIL & $9 \mathrm{p} 21.3$ & Oncogenic & p15, miR-186, PI3K/Akt pathway & {$[273]$} \\
BCAR4 & $16 \mathrm{p} 13.13$ & Oncogenic & EMT process & {$[260]$} \\
H19 & $11 \mathrm{p} 15.5$ & Oncogenic & miR-138-5p & [163] \\
GAS5 & $1 \mathrm{q} 25.1$ & Tumor suppressor & Akt, miR-106b, IER3 & 257,258] \\
\hline
\end{tabular}


Table 3. Cont

\begin{tabular}{|c|c|c|c|c|}
\hline LncRNAs & Locus & Status & Target/Function & References \\
\hline SNHG20 & $17 q 25.2$ & Oncogenic & miR-140-5p/ADAM10 axis & [274] \\
\hline MALAT1 & $11 \mathrm{q} 13.1$ & Oncogenic & $\begin{array}{l}\text { IL-6/STAT3, HPV18 E6/E7, PI3K/AKT signaling } \\
\text { pathways, miR-145/Cyclin D1, miR-625-5p/NF-кB }\end{array}$ & {$[184,202,205,206]$} \\
\hline XIST & Xq13 & Oncogenic & $\begin{array}{l}\text { miR-889-3p/SIX1 axis, miR-23a-3p/LGR4 miR-30b-5p, } \\
\text { miR-30c-5p, miR-30e-5p I ADAM9 }\end{array}$ & {$[275,276]$} \\
\hline UCA1 & $19 \mathrm{p} 13.12$ & Oncogenic & VEGF, miR-206 & [267] \\
\hline LET & - & Tumor suppressor & Unknown & [273] \\
\hline MEG3 & $14 \mathrm{q} 32.3$ & Tumor suppressor & miR-21-5p, miR-7-5p/SCT1, miR-421/BTG1, P-STAT3 & [237-240] \\
\hline CCAT2 & $8 \mathrm{q} 24.21$ & Oncogenic & $\begin{array}{l}\text { TCF7L2, MYC, miR-17-5p, miR20a, Wnt/ } \beta \text {-catenin } \\
\text { signaling pathway }\end{array}$ & [258] \\
\hline SBF2-AS1 & 11p15.1 & Oncogenic & miR-361-5p/FOXM1 axis & [277] \\
\hline EBIC & $16 q$ & Oncogenic & E-cadherin/EZH2, & {$[258,273]$} \\
\hline LUCAT1 & $5 q 14.3$ & Oncogenic & MTA1, miR-181a, miR-199b-5p & [251] \\
\hline PVT1 & $8 \mathrm{q} 24$ & Oncogenic & miR-200b/EZH2, miR-128-3p, miR-424 & {$[258,277]$} \\
\hline CCHE1 & $10 \mathrm{q} 21.1$ & Oncogenic & PCNA & [273] \\
\hline TUG1 & $22 \mathrm{q} 12.2$ & Oncogenic & miR-138-5p/SIRT1, Wnt/ $\beta$-catenin signaling pathway & [278] \\
\hline NEAT1 & $11 \mathrm{q} 13.1$ & Oncogenic & $\begin{array}{c}\mathrm{miR}-124 / \mathrm{NF}-\mathrm{kB}, \mathrm{miR}-889-3 \mathrm{p} / \mathrm{E} 2 \mathrm{~F} 7 / \mathrm{PI} 3 \mathrm{~K} / \mathrm{AKT} \\
\text { miR-361/HSP90 }\end{array}$ & {$[134,135,138]$} \\
\hline PCAT1 & $8 \mathrm{q} 24$ & Oncogenic & Unknown & [270] \\
\hline LncRNA-ATB & chr 13,14 and 22 & Oncogenic & miR-144/ITGA6 axis & [252] \\
\hline SPRY4-IT1 & - & Oncogenic & MiR-101-3p, E-cadherin, vimentin, ZEB1, EMT & [236] \\
\hline ZFAS1 & $20 q 13.13$ & Oncogenic & Unknown & [263] \\
\hline
\end{tabular}

Table 4. LncRNAs involved in proliferation, invasion, apoptosis, migration, metastasis, and drug resistance in ovarian cancers.

\begin{tabular}{|c|c|c|c|c|}
\hline LncRNAs & Locus & Status & Target/Function & References \\
\hline HOTTIP & $7 \mathrm{p} 15.2$ & Oncogenic & $\begin{array}{l}\text { Wnt } / \beta \text {-catenin, STAT3 signaling pathways, } \\
\text { IL-6/PD-L1, c-jun }\end{array}$ & [250] \\
\hline NEAT1 & 11q13.1 & Oncogenic & $\begin{array}{l}\text { EMT via miR-365/FGF9, miR-1321/TJP3, } \\
\text { miR-4500/BZW1 axis, miR-770-5p/PARP1 }\end{array}$ & [139-141,143] \\
\hline HOXA11-AS & $7 \mathrm{p} 15.2$ & Tumor suppressor & Unknown & {$[22]$} \\
\hline PVT1 & $8 \mathrm{q} 24$ & Oncogenic & $\begin{array}{l}\text { miRNA133a, miR-140, s TGF- } \beta 1, \text { p-SMAD4, } \\
\text { CASPASE-3 }\end{array}$ & [264] \\
\hline AB073614 & $3 q 24$ & Oncogenic & $\begin{array}{l}\text { p-Akt, PTEN, PI3K/Akt, ERK pathways, BCL-2, BAK, } \\
\text { BAX, N-cadherin, vimentin, MMP2, EMT }\end{array}$ & [279] \\
\hline ABHD11-AS1 & 7 q11. 23. & Oncogenic & $\begin{array}{c}\text { RhoC/PI3K/Akt signaling, RhoC/P70s6k, } \\
\text { RhoC/BCL-xL }\end{array}$ & [279] \\
\hline DANCR & $4 q 12$ & Oncogenic & IGF2 & {$[256,280]$} \\
\hline FAS-AS1 & $10 q 23.31$ & Oncogenic & Unknown & [281] \\
\hline aHIF & - & Oncogenic & Unknown & [282] \\
\hline FAM83H-AS1 & $8 \mathrm{q} 24.3$ & Oncogenic & HuR protein & {$[261,282]$} \\
\hline HOST2 & $10 \mathrm{q} 23.1$ & Oncogenic & miRNA let-7 & [264] \\
\hline $\begin{array}{l}\text { ADAMTS9- } \\
\text { AS2 }\end{array}$ & 3p14. 1 & Tumor suppressor & miR-182-5p/FOXF2 signaling pathway & [279] \\
\hline CASC2 & $10 q 26$ & Tumor suppressor & EIF4A3, PI3K/AKT/mTOR pathway, NF-кB signaling & {$[282,283]$} \\
\hline ANRIL & $9 \mathrm{p} 21.3$ & Oncogenic & let-7a, HMGA2, MMP3, MET, cyclin D1-CDK4/6 & {$[264]$} \\
\hline FEZF1-AS1 & $7 q 31.32$ & Oncogenic & miR-130a-5p/SOX4 axis. & [284] \\
\hline DUXAP10 & $14 \mathrm{q} 11.2$ & Oncogenic & $\begin{array}{c}\text { VEGF, MMP-9, E-cadherin, B-catenin, Snail, vimentin, } \\
\text { Twist }\end{array}$ & {$[97,285]$} \\
\hline ASAP1-IT1 & & Tumor suppressor & Hippo/YAP signaling & [286] \\
\hline GAS5 & $1 \mathrm{q} 25.1$ & Tumor suppressor & miR-196a-5p & [257] \\
\hline $\begin{array}{l}\text { EPB41L4A- } \\
\text { AS2 }\end{array}$ & - & Tumor suppressor & microRNA-103a/RUNX1T1 & [287] \\
\hline GHET1 & $7 q 36.1$ & Oncogenic & HIF1a/VEGF & [282] \\
\hline $\mathrm{JPX}$ & - & Oncogenic & PI3K/Akt/mTOR pathway & [288] \\
\hline CCAT1 & $8 \mathrm{q} 24.21$ & Oncogenic & miR-490-3p, miR-1290, miR-3679, TGF $\beta R 1$ & [264] \\
\hline CCAT2 & $8 \mathrm{q} 24.21$ & Oncogenic & Wnt/beta-catenin pathway miR-424 & {$[97,264]$} \\
\hline
\end{tabular}


Table 4. Cont

\begin{tabular}{|c|c|c|c|c|}
\hline LncRNAs & Locus & Status & Target/Function & References \\
\hline HAGLROS & $2 \mathrm{q} 31.1$ & Oncogenic & miR-100/mTOR, miR-100/ZNRF2 & [289] \\
\hline CPS1-IT1 & - & $\begin{array}{l}\text { Tumor } \\
\text { Suppressor }\end{array}$ & BAX, caspase-9, BCL-2 & [279] \\
\hline LUCAT1 & $5 q 14.3$ & Oncogenic & $\begin{array}{l}\text { miR-612/HOXA13 axis, miR-612/HOXA13, } \\
\text { miR-199a-5p }\end{array}$ & {$[251,281]$} \\
\hline HOTAIR & $12 q 13.13$ & Oncogenic & $\begin{array}{l}\text { EMT-related genes, MMPs, miR-206/TBX3 axis, } \\
\text { miR-138-5p/CHEK1 }\end{array}$ & $\begin{array}{c}{[117,118,120,} \\
121]\end{array}$ \\
\hline DLEU1 & $13 q 14.3$ & Oncogenic & miR-490-3p/CDK1 expression & {$[282,290]$} \\
\hline EIBC & - & Oncogenic & Wnt $/ \beta$-catenin & [97] \\
\hline MALAT1 & $11 q 13.1$ & Oncogenic & $\begin{array}{c}\text { YAP, Notch1 signaling pathway, miR-143-3p/CMPK, } \\
\text { miR-503-5p/JAK2-STAT3, miR-200c, EMT via RBFOX2, } \\
\text { KIF1B, } \beta \text {-catenin, DVL2, cyclin D1, Wnt/ } \beta \text {-catenin } \\
\text { signaling pathway }\end{array}$ & {$[182,207-212]$} \\
\hline MNX1-AS1 & - & Oncogenic & CDK4, cyclin D, BCL-2, BAX & [97] \\
\hline MEG3 & $14 q 32.3$ & Tumor suppressor & $\begin{array}{l}\text { PTEN, miR-205-5p, miR-219a-5p/EGFR axis, } \\
\text { miR-421/PDGFRA axis, Notch1 pathway }\end{array}$ & [242-246] \\
\hline SNHG15 & $7 \mathrm{p} 13$ & Oncogenic & miR-18a, AKT/mTOR signalling pathway & [264] \\
\hline XIST1 & Xq13.2 & Tumor suppressor & miR-150-5p & [264] \\
\hline Linc-ROR & $18 \mathrm{q} 21.31$ & Oncogenic & EMT via $W n t / \beta$-catenin signaling & [291] \\
\hline NBAT1 & $6 p 22.3$ & Tumor suppressor & ERK $1 / 2$, Akt pathways & [279] \\
\hline UCA1 & $19 \mathrm{p} 13.12$ & Oncogenic & miR-129/ABCB1 axis, SRPK1 & [259] \\
\hline lncBRM & 1 & Oncogenic & Sox 4, miR-204 & [97] \\
\hline H19 & 11p15.5 & Oncogenic & EMT via miR-370-3p/TGF- $\beta$ pathway, IGF2 & {$[165,167]$} \\
\hline ZFAS1 & $20 \mathrm{q} 13.13$ & Oncogenic & $\begin{array}{l}\text { miR-548e, let-7a, E-cadherin, N-cadherin CXCR4, } \\
\text { Vimentin, MMP-2, BCLXL, miR-150-5p, KLF2, } \\
\text { miR-129-5p, cyclin D1/CDK4, NEK2/Wnt pathway, }\end{array}$ & [263] \\
\hline PCAT1 & $8 q 24$ & Oncogenic & $\begin{array}{c}\text { miR-124-3p/cyclin D1, CDK6, p53, BAX, cleaved } \\
\text { caspase-3, metallopeptidases, vimentin, Wnt3a, } \\
\beta \text {-catenin }\end{array}$ & [270] \\
\hline
\end{tabular}

Table 5. LncRNAs involved in proliferation, invasion, apoptosis, migration, metastasis, and drug resistance in vulvar cancers.

\begin{tabular}{ccccc}
\hline LncRNAs & Locus & Status & Target/Function & References \\
\hline HOTAIR & $12 \mathrm{q} 13.13$ & Oncogenic & Unknown & {$[122]$} \\
MALAT1 & $11 \mathrm{q} 13.1$ & Oncogenic & Unknown & {$[213,214]$} \\
MIR31HG & $9 \mathrm{p} 21.3$ & Oncogenic & p16INK4A & {$[292]$} \\
NEAT1 & $11 \mathrm{q} 13.1$ & Oncogenic & Unknown & {$[144]$} \\
ROCK1 & - & Oncogenic & Unknown & {$[293]$} \\
UCA1 & $19 \mathrm{p} 13.12$ & Oncogenic & miR-103a/WEE1 & {$[294]$} \\
\hline
\end{tabular}

Table 6. LncRNAs involved in proliferation, invasion, apoptosis, migration, metastasis, and drug resistance in GTN.

\begin{tabular}{|c|c|c|c|c|}
\hline LncRNAs & Locus & Status & Target/Function & References \\
\hline OGFRP1 & $22 \mathrm{q} 13.2$ & Oncogenic & $\mathrm{AKT} / \mathrm{mTOR}$ & [295] \\
\hline LINC00261 & 20p11.21 & Tumor suppressor & Unknown & [295] \\
\hline MALAT1 & $11 q 13.1$ & Oncogenic & miR-218/Fbxw8 & [215] \\
\hline PCA3 & $9 q 21-22$ & Oncogenic & miR-106b & [295] \\
\hline MEG3 & $14 q 32.3$ & Tumor suppressor & $\begin{array}{c}\text { miR-211/PI3K/AKT and AMPK pathways, } \\
\text { PI3K/AKT/NF- } \text { / B signaling pathway }\end{array}$ & {$[247,248]$} \\
\hline MIR503HG & Xq26 & Tumor suppressor & Unknown & [295] \\
\hline H19 & $11 \mathrm{p} 15.5$ & Oncogenic & $\mathrm{PI} 3 \mathrm{~K} / \mathrm{AKT} / \mathrm{mTOR}$ & [170] \\
\hline LOXL1-AS1 & - & Tumor suppressor & miR-515-5p/NF- $\kappa B$ signaling pathway & \\
\hline SPRY4-IT1 & - & Oncogenic & EMT process & [296] \\
\hline
\end{tabular}




\section{Closing Remarks and Future Directions}

The status of lncRNAs will change day by day with more and more knowledge and understanding in molecular biology and oncology. By understanding the underlying mechanisms and functions of lncRNAs in cancer cells, efficient therapeutic approaches could be determined. Furthermore, it is expected that lncRNAs might be used as potential biomarkers for early diagnosis or prognosis of cancer because of their aberrant changes during cancer progression, such as the use of lncRNA PCA3 for early diagnosis of prostate cancer with high sensitivity and specificity [297]. The actual application of lncRNAs as potential biomarkers and targets for diagnosis and therapy has broad prospects for future cancer treatment and for modifying therapy according to the needs of individual patients. However, significant development and research efforts are still needed to determine the utilization of lncRNAs-based technologies in clinical utility.

Author Contributions: F.N.: Conceptualization, writing, review, editing, manuscript drafting including figures. I.T.: Conceptualization, supervision, review, visualization, manuscript drafting. S.A.: Writing, review, editing, visualization. A.S.: Writing, review, editing, visualization. E.P.: Writing, review, editing, visualization. U.B.: Supervision, project administration, funding acquisition, review, editing. All authors have read and agreed to the published version of the manuscript.

Funding: This research received no external funding.

Acknowledgments: The authors are grateful to the University of the Punjab, Lahore, Pakistan, and Philipps University of Marburg, Germany, to provide the research platform.

Conflicts of Interest: The authors declare no conflict of interest.

\section{Abbreviations}

p54nrb $54 \mathrm{KDa}$ nuclear RNA and DNA-binding proteins

AMP AMP-activated protein kinase

ANGPTL1 Angiopoietin-related protein 1

BTG1 BTG anti-proliferation factor 1

CDC42 Cell division cycle 42

DVL2 Disheveled Segment Polarity Protein 2

DUSP5 Dual-specific phosphatase 5

EGFR Epidermal growth factor receptor

ER+ BC Estrogen receptor-positive BC

Fbxw8 F-box/WD repeat-containing protein 8

FGF Fibroblast growth factor

FDA Food and drug administration

FOXO1 Forkhead Box O1

HES-1 Hairy and enhancer of split homolog-1

HMGA2 High-mobility group AT-hook 2

HOXA10 homeobox gene A10

HER2 Human epidermal growth factor receptor 2

FIGO International Federation of Gynecology and Obstetrics

KIF1B Kinesin Family Member 1B

LAMA4 Laminin Subunit Alpha 4

lincRNA Long intergenic non-coding RNA

KDM5B Lysine-specific demethylase 5B protein

NEAT2 Nuclear enriched abundant transcript 2

OSCC Oral squamous cell carcinoma

PSPC1 Paraspeckle component 1

PBLD Phenazine biosynthesis like protein domain-containing

PDGFRA Platelet-Derived Growth Factor Receptor Alpha

PARP1 Poly adenosine diphosphate-ribose polymerase 1

2PRC2 Poly comb recessive complex

RALGAPA2 Ral GTPase Activating Protein Catalytic Subunit Alpha 2 


$\begin{array}{ll}\text { RBFOX2 } & \text { RNA Binding Fox-1 Homolog } 2 \\ \text { RBPs } & \text { RNA-binding proteins } \\ \text { STAT3 } & \text { Signal transducer and activator of transcription } 3 \\ \text { SNHG3 } & \text { Small nucleolar host gene 3 } \\ \text { SFPQ } & \text { Splicing factor proline/glutamine-rich } \\ \text { STC1 } & \text { Stanniocalcin-1 } \\ \text { TIMD4 } & \text { T cell Immunoglobulin and Mucin Domain } 4 \\ \text { TJP3 } & \text { Tight junction protein } 3 \text { expression } \\ \text { TGF } \beta & \text { Transforming growth factor } \beta \\ \text { TAK1 } & \text { Transforming growth factor- } \beta \text { activated kinase 1 } \\ \text { TGF- } \beta & \text { Transforming growth factor- } \beta \\ \text { TEF1A1 } & \text { Translation elongation factor 1-alpha 1 gene } \\ \text { TM } & \text { Tumor microenvironment } \\ \text { TNFAIP8 } & \text { Tumor necrosis factor } \alpha \text {-induced protein } 8 \\ \text { XBP1-HIF-1 } \alpha & \text { X-box binding protein } 1 \text { - hypoxia-inducible factor } \\ \text { YAP } & \text { Yes-associated protein }\end{array}$

\section{References}

1. Zampetaki, A.; Albrecht, A.; Steinhofel, K. Long non-coding RNA structure and function: Is there a link? Front. Physiol. 2018, 9, 1201. [CrossRef]

2. Kazimierczyk, M.; Kasprowicz, M.K.; Kasprzyk, M.E.; Wrzesinski, J. Human long noncoding RNA interactome: Detection, characterization and function. Int. J. Mol. Sci. 2020, 21, 1027. [CrossRef]

3. Amin, N.; McGrath, A.; Chen, Y.-P.P. Evaluation of deep learning in non-coding RNA classification. Nat. Mach. Intell. 2019, 1, 246-256. [CrossRef]

4. Frankish, A.; Diekhans, M.; Ferreira, A.-M.; Johnson, R.; Jungreis, I.; Loveland, J.; Mudge, J.M.; Sisu, C.; Wright, J.; Armstrong, J. GENCODE reference annotation for the human and mouse genomes. Nucleic Acids Res. 2019, 47, D766-D773. [CrossRef] [PubMed]

5. Yi, K.; Zhang, Y.; Wang, Y.; Wang, Z.; Xie, M.; Jin, Z.; Zhao, T. Long noncoding RNA and its role in virus infection and pathogenesis. Front. Biosci. 2019, 24, 777-789.

6. Uszczynska-Ratajczak, B.; Lagarde, J.; Frankish, A.; Guigó, R.; Johnson, R. Towards a complete map of the human long non-coding RNA transcriptome. Nat. Rev. Genet. 2018, 19, 535-548. [CrossRef] [PubMed]

7. Dahariya, S.; Paddibhatla, I.; Kumar, S.; Raghuwanshi, S.; Pallepati, A.; Gutti, R.K. Long non-coding RNA: Classification, biogenesis and functions in blood cells. Mol. Immunol. 2019, 112, 82-92. [CrossRef] [PubMed]

8. Miao, H.; Wang, L.; Zhan, H.; Dai, J.; Chang, Y.; Wu, F.; Liu, T.; Liu, Z.; Gao, C.; Li, L. A long noncoding RNA distributed in both nucleus and cytoplasm operates in the PYCARD-regulated apoptosis by coordinating the epigenetic and translational regulation. PLoS Genet. 2019, 15, e1008144. [CrossRef]

9. Ang, C.E.; Trevino, A.E.; Chang, H.Y. Diverse lncRNA mechanisms in brain development and disease. Curr. Opin. Genet. Dev. 2020, 65, 42-46. [CrossRef]

10. Aillaud, M.; Schulte, L.N. Emerging Roles of Long Noncoding RNAs in the Cytoplasmic Milieu. Non-Coding RNA 2020, 6, 44. [CrossRef]

11. Guh, C.-Y.; Hsieh, Y.-H.; Chu, H.-P. Functions and properties of nuclear lncRNAs-From systematically mapping the interactomes of lncRNAs. J. Biomed. Sci. 2020, 27, 1-14. [CrossRef]

12. Graf, J.; Kretz, M. From structure to function: Route to understanding lncRNA mechanism. BioEssays 2020, 42, 2000027. [CrossRef] [PubMed]

13. Karner, H.; Webb, C.-H.; Carmona, S.; Liu, Y.; Lin, B.; Erhard, M.; Chan, D.; Baldi, P.; Spitale, R.C.; Sun, S. Functional conservation of lncRNA JPX despite sequence and structural divergence. J. Mol. Biol. 2020, 432, 283-300. [CrossRef]

14. Anbari, D.M.; Al-Harithy, R.N. Ghrelin intronic lncRNAs, lnc-GHRL-3: 2 and lnc-GHRL-3: 3, as novel biomarkers in type 2 diabetes mellitus. Arch. Physiol. Biochem. 2020, 1-5. [CrossRef]

15. Kong, S.; Tao, M.; Shen, X.; Ju, S. Translatable circRNAs and lncRNAs: Driving mechanisms and functions of their translation products. Cancer Lett. 2020, 483, 59-65. [CrossRef] [PubMed]

16. Lorenzi, L.; Avila Cobos, F.; Decock, A.; Everaert, C.; Helsmoortel, H.; Lefever, S.; Verboom, K.; Volders, P.J.; Speleman, F.; Vandesompele, J. Long noncoding RNA expression profiling in cancer: Challenges and opportunities. Genes Chromosomes Cancer 2019, 58, 191-199. [CrossRef] [PubMed]

17. Torre, L.A.; Islami, F.; Siegel, R.L.; Ward, E.M.; Jemal, A. Global cancer in women: Burden and trends. Cancer Epidemiol. Prev. Biomark. 2017, 26, 444-457. [CrossRef]

18. Farmer, P.; Frenk, J.; Knaul, F.M.; Shulman, L.N.; Alleyne, G.; Armstrong, L.; Atun, R.; Blayney, D.; Chen, L.; Feachem, R. Expansion of cancer care and control in countries of low and middle income: A call to action. Lancet 2010, 376, 1186-1193. [CrossRef] 
19. Chen, Z.; Xu, L.; Shi, W.; Zeng, F.; Zhuo, R.; Hao, X.; Fan, P. Trends of female and male breast cancer incidence at the global, regional, and national levels, 1990-2017. Breast Cancer Res. Treat. 2020, 180, 481-490. [CrossRef]

20. Nero, C.; Ciccarone, F.; Pietragalla, A.; Scambia, G. PTEN and gynecological cancers. Cancers 2019, 11, 1458. [CrossRef] [PubMed]

21. Bin, X.; Hongjian, Y.; Xiping, Z.; Bo, C.; Shifeng, Y.; Binbin, T. Research progresses in roles of LncRNA and its relationships with breast cancer. Cancer Cell Int. 2018, 18, 1-12. [CrossRef] [PubMed]

22. Wei, C.; Zhao, L.; Liang, H.; Zhen, Y.; Han, L. Recent advances in unraveling the molecular mechanisms and functions of HOXA11-AS in human cancers and other diseases. Oncol. Rep. 2020, 43, 1737-1754. [CrossRef] [PubMed]

23. Costantino, C.; Alba, D.; Cimino, L.; Conforto, A.; Mazzucco, W. The Role of Vaccination and Screening in Limiting the Worldwide Disease Burden of Preventable Female Cancers: A Review. Women 2021, 1, 16-28. [CrossRef]

24. Sonnenschein, C.; Soto, A.M. Carcinogenesis explained within the context of a theory of organisms. Prog. Biophys. Mol. Biol. 2016, 122, 70-76. [CrossRef] [PubMed]

25. Dumars, C.; Ngyuen, J.-M.; Gaultier, A.; Lanel, R.; Corradini, N.; Goudin, F.; Heymann, D. Dysregulation of macrophage polarization is associated with the metastatic process in osteosarcoma. Oncotarget 2016, 7, 78343-78354. [CrossRef] [PubMed]

26. Basse, C.; Arock, M. The increasing roles of epigenetics in breast cancer: Implications for pathogenicity, biomarkers, prevention and treatment. Int. J. Cancer 2015, 137, 2785-2794. [CrossRef] [PubMed]

27. Crabtree, J.S.; Miele, L. Breast cancer stem cells. Biomedicines 2018, 6, 77. [CrossRef]

28. Brooks, R.A.; Fleming, G.F.; Lastra, R.R.; Lee, N.K.; Moroney, J.W.; Son, C.H.; Tatebe, K.; Veneris, J.L. Current recommendations and recent progress in endometrial cancer. CA Cancer J. Clin. 2019, 69, 258-279. [CrossRef]

29. Lortet-Tieulent, J.; Ferlay, J.; Bray, F.; Jemal, A. International patterns and trends in endometrial cancer incidence, 1978-2013. JNCI J. Natl. Cancer Inst. 2018, 110, 354-361. [CrossRef]

30. Morice, P.; Leary, A.; Creutzberg, C.; Abu-Rustum, N.; Darai, E. Endometrial cancer. Lancet 2016, 387, 1094-1108. [CrossRef]

31. Dörk, T.; Hillemanns, P.; Tempfer, C.; Breu, J.; Fleisch, M.C. Genetic susceptibility to endometrial cancer: Risk factors and clinical management. Cancers 2020, 12, 2407. [CrossRef] [PubMed]

32. Arbyn, M.; Weiderpass, E.; Bruni, L.; de Sanjosé, S.; Saraiya, M.; Ferlay, J.; Bray, F. Estimates of incidence and mortality of cervical cancer in 2018: A worldwide analysis. Lancet Global Health 2020, 8, e191-e203. [CrossRef]

33. Lei, J.; Ploner, A.; Elfström, K.M.; Wang, J.; Roth, A.; Fang, F.; Sundström, K.; Dillner, J.; Sparén, P. HPV vaccination and the risk of invasive cervical cancer. N. Engl. J. Med. 2020, 383, 1340-1348. [CrossRef]

34. Small Jr, W.; Bacon, M.A.; Bajaj, A.; Chuang, L.T.; Fisher, B.J.; Harkenrider, M.M.; Jhingran, A.; Kitchener, H.C.; Mileshkin, L.R.; Viswanathan, A.N. Cervical cancer: A global health crisis. Cancer 2017, 123, 2404-2412. [CrossRef] [PubMed]

35. Sachan, P.L.; Singh, M.; Patel, M.L.; Sachan, R. A study on cervical cancer screening using pap smear test and clinical correlation. Asia-Pac. J. Oncol. Nurs. 2018, 5, 337. [CrossRef] [PubMed]

36. Jessmon, P.; Boulanger, T.; Zhou, W.; Patwardhan, P. Epidemiology and treatment patterns of epithelial ovarian cancer. Expert Rev. Anticancer Ther. 2017, 17, 427-437. [CrossRef] [PubMed]

37. Torre, L.A.; Trabert, B.; DeSantis, C.E.; Miller, K.D.; Samimi, G.; Runowicz, C.D.; Gaudet, M.M.; Jemal, A.; Siegel, R.L. Ovarian cancer statistics, 2018. CA Cancer J. Clin. 2018, 68, 284-296. [CrossRef] [PubMed]

38. Nash, Z.; Menon, U. Ovarian cancer screening: Current status and future directions. Best Pract. Res. Clin. Obstet. Gynaecol. 2020, 65, 32-45. [CrossRef]

39. Abrar, R.; Muhammad, S. Primary Fallopian Tube Carcinoma: A Case Report. Andalas Obstet. Gynecol. J. 2021, 5, 130-138. [CrossRef]

40. Yang, Y.; Xiao, Z.; Liu, Z.; Lv, F. MRI can be used to differentiate between primary fallopian tube carcinoma and epithelial ovarian cancer. Clin. Radiol. 2020, 75, 457-465. [CrossRef] [PubMed]

41. Siegel, R.; Ma, J.; Zou, Z.; Jemal, A. Cancer statistics, 2014. CA Cancer J. Clin. 2014, 64, 9-29. [CrossRef]

42. Adams, T.S.; Cuello, M.A. Cancer of the vagina. Int. J. Gynecol. Obstet. 2018, 143, 14-21. [CrossRef]

43. Mantovani, G.; Fragomeni, S.M.; Inzani, F.; Fagotti, A.; Della Corte, L.; Gentileschi, S.; Tagliaferri, L.; Zannoni, G.F.; Scambia, G.; Garganese, G. Molecular pathways in vulvar squamous cell carcinoma: Implications for target therapeutic strategies. J. Cancer Res. Clin. Oncol. 2020, 146, 1647-1658.

44. Weinberg, D.; Gomez-Martinez, R.A. Vulvar cancer. Obstet. Gynecol. Clin. 2019, 46, 125-135. [CrossRef]

45. Ni, S.; Zhao, X.; Ouyang, L. Long non-coding RNA expression profile in vulvar squamous cell carcinoma and its clinical significance. Oncol. Rep. 2016, 36, 2571-2578. [CrossRef]

46. Bruce, S.; Sorosky, J. Gestational Trophoblastic Disease; StatPearls: Treasure Island, FL, USA, 2020.

47. Sharami, S.R.Y.; Saffarieh, E. A review on management of gestational trophoblastic neoplasia. J. Fam. Med. Prim. Care 2020, 9, 1287.

48. Clark, J.J.; Slater, S.; Seckl, M.J. Treatment of gestational trophoblastic disease in the 2020s. Curr. Opin. Obstet. Gynecol. 2021, 33, 7-12. [CrossRef]

49. Qin, T.; Li, J.; Zhang, K.-Q. Structure, regulation, and function of linear and circular long Non-Coding RNAs. Front. Genet. 2020, 11, 150. [CrossRef] [PubMed]

50. Pathania, A.S.; Challagundla, K.B. Exosomal long non-coding RNAs: Emerging players in the tumor microenvironment. Mol. Ther.-Nucleic Acids 2020, 8, 769-780. [CrossRef] 
51. Beckedorff, F.C.; Ayupe, A.C.; Crocci-Souza, R.; Amaral, M.S.; Nakaya, H.I.; Soltys, D.T.; Menck, C.F.; Reis, E.M.; VerjovskiAlmeida, S. The intronic long noncoding RNA ANRASSF1 recruits PRC2 to the RASSF1A promoter, reducing the expression of RASSF1A and increasing cell proliferation. PLoS Genet. 2013, 9, e1003705. [CrossRef]

52. Huarte, M.; Guttman, M.; Feldser, D.; Garber, M.; Koziol, M.J.; Kenzelmann-Broz, D.; Khalil, A.M.; Zuk, O.; Amit, I.; Rabani, M. A large intergenic noncoding RNA induced by p53 mediates global gene repression in the p53 response. Cell 2010, 142, 409-419. [CrossRef]

53. Mozdarani, H.; Ezzatizadeh, V.; Rahbar Parvaneh, R. The emerging role of the long non-coding RNA HOTAIR in breast cancer development and treatment. J. Transl. Med. 2020, 18, 1-15. [CrossRef] [PubMed]

54. Zacharopoulou, E.; Gazouli, M.; Tzouvala, M.; Vezakis, A.; Karamanolis, G. The contribution of long non-coding RNAs in Inflammatory Bowel Diseases. Dig. Liver Dis. 2017, 49, 1067-1072. [CrossRef] [PubMed]

55. Gayen, S.; Maclary, E.; Buttigieg, E.; Hinten, M.; Kalantry, S. A primary role for the Tsix lncRNA in maintaining random X-chromosome inactivation. Cell Rep. 2015, 11, 1251-1265. [CrossRef]

56. Fernandes, J.C.; Acuña, S.M.; Aoki, J.I.; Floeter-Winter, L.M.; Muxel, S.M. Long non-coding RNAs in the regulation of gene expression: Physiology and disease. Non-Coding RNA 2019, 5, 17. [CrossRef] [PubMed]

57. Shigeyasu, K.; Toden, S.; Ozawa, T.; Matsuyama, T.; Nagasaka, T.; Ishikawa, T.; Sahoo, D.; Ghosh, P.; Uetake, H.; Fujiwara, T. The PVT1 lncRNA is a novel epigenetic enhancer of MYC, and a promising risk-stratification biomarker in colorectal cancer. Mol. Cancer 2020, 19, 1-6. [CrossRef]

58. Kim, T.-K.; Hemberg, M.; Gray, J.M. Enhancer RNAs: A class of long noncoding RNAs synthesized at enhancers. Cold Spring Harb. Perspect. Biol. 2015, 7, a018622. [CrossRef]

59. Sartorelli, V.; Lauberth, S.M. Enhancer RNAs are an important regulatory layer of the epigenome. Nat. Struct. Mol. Biol. 2020, 27, 521-528. [CrossRef]

60. Kirk, J.M.; Kim, S.O.; Inoue, K.; Smola, M.J.; Lee, D.M.; Schertzer, M.D.; Wooten, J.S.; Baker, A.R.; Sprague, D.; Collins, D.W. Functional classification of long non-coding RNAs by k-mer content. Nat. Genet. 2018, 50, 1474-1482. [CrossRef]

61. Kopp, F.; Mendell, J.T. Functional classification and experimental dissection of long noncoding RNAs. Cell 2018, $172,393-407$. [CrossRef] [PubMed]

62. Rinn, J.L.; Kertesz, M.; Wang, J.K.; Squazzo, S.L.; Xu, X.; Brugmann, S.A.; Goodnough, L.H.; Helms, J.A.; Farnham, P.J.; Segal, E. Functional demarcation of active and silent chromatin domains in human HOX loci by noncoding RNAs. Cell 2007, 129, 1311-1323. [CrossRef] [PubMed]

63. Liu, M.; Ren, J. Long noncoding RNAs in renal diseases. ExRNA 2019, 1, 1-9. [CrossRef]

64. Gao, Y.; Li, X.; Shang, S.; Guo, S.; Wang, P.; Sun, D.; Gan, J.; Sun, J.; Zhang, Y.; Wang, J. LincSNP 3.0: An updated database for linking functional variants to human long non-coding RNAs, circular RNAs and their regulatory elements. Nucleic Acids Res. 2021, 49, D1244-D1250. [CrossRef]

65. Quinn, J.J.; Chang, H.Y. Unique features of long non-coding RNA biogenesis and function. Nat. Rev. Genet. 2016, 17, 47. [CrossRef]

66. Sun, W.; Ren, S.; Li, R.; Zhang, Q.; Song, H. LncRNA, a novel target biomolecule, is involved in the progression of colorectal cancer. Am. J. Cancer Res. 2019, 9, 2515.

67. Gonzalez, I.; Munita, R.; Agirre, E.; Dittmer, T.A.; Gysling, K.; Misteli, T.; Luco, R.F. A lncRNA regulates alternative splicing via establishment of a splicing-specific chromatin signature. Nat. Struct. Mol. Biol. 2015, 22, 370-376. [CrossRef] [PubMed]

68. Dhanoa, J.K.; Sethi, R.S.; Verma, R.; Arora, J.S.; Mukhopadhyay, C.S. Long non-coding RNA: Its evolutionary relics and biological implications in mammals: A review. J. Anim. Sci. Technol. 2018, 60, 1-10. [CrossRef] [PubMed]

69. Li, S.; Shen, L.; Chen, K.N. Association between H3K4 methylation and cancer prognosis: A meta-analysis. Thorac. Cancer 2018, 9 , 794-799. [CrossRef]

70. Cao, M.; Zhao, J.; Hu, G. Genome-wide methods for investigating long noncoding RNAs. Biomed. Pharmacother. 2019, 111, 395-401. [CrossRef]

71. Nandwani, A.; Rathore, S.; Datta, M. LncRNAs in cancer: Regulatory and therapeutic implications. Cancer Lett. 2021, 501, $162-171$. [CrossRef]

72. Zhang, R.; Xia, L.Q.; Lu, W.W.; Zhang, J.; Zhu, J.S. LncRNAs and cancer. Oncol. Lett. 2016, 12, 1233-1239. [CrossRef] [PubMed]

73. Begolli, R.; Sideris, N.; Giakountis, A. LncRNAs as chromatin regulators in cancer: From molecular function to clinical potential. Cancers 2019, 11, 1524. [CrossRef]

74. Zhang, K.; Shi, H.; Xi, H.; Wu, X.; Cui, J.; Gao, Y.; Liang, W.; Hu, C.; Liu, Y.; Li, J. Genome-wide lncRNA microarray profiling identifies novel circulating lncRNAs for detection of gastric cancer. Theranostics 2017, 7, 213. [CrossRef]

75. Liu, F.; Ai, F.Y.; Zhang, D.C.; Tian, L.; Yang, Z.Y.; Liu, S.J. LncRNA NEAT1 knockdown attenuates autophagy to elevate 5e 5iling identifies novel circulating lncRNAs fong miR-34a. Cancer Med. 2020, 9, 1079-1091. [CrossRef] [PubMed]

76. Pisani, G.; Baron, B. NEAT1 and paraspeckles in cancer development and chemoresistance. Non-Coding RNA 2020, 6, 43. [CrossRef]

77. Guo, X.; Xiao, H.; Guo, S.; Li, J.; Wang, Y.; Chen, J.; Lou, G. Long noncoding RNA HOTAIR knockdown inhibits autophagy and epithelial-mesenchymal transition through the Wnt signaling pathway in radioresistant human cervical cancer HeLa cells. J. Cell. Physiol. 2019, 234, 3478-3489. [CrossRef] [PubMed]

78. Zhang, Y.; Ai, H.; Fan, X.; Chen, S.; Wang, Y.; Liu, L. Knockdown of long non-coding RNA HOTAIR reverses cisplatin resistance of ovarian cancer cells through inhibiting miR-138-5p-regulated EZH2 and SIRT1. Biol. Res. 2020, 53, 1-10. [CrossRef] 
79. Peng, L.; Jiang, J.; Tang, B.; Nice, E.C.; Zhang, Y.-Y.; Xie, N. Managing therapeutic resistance in breast cancer: From the lncRNAs perspective. Theranostics 2020, 10, 10360. [CrossRef]

80. Xiu, D.-H.; Liu, G.-F.; Yu, S.-N.; Li, L.-Y.; Zhao, G.-Q.; Liu, L.; Li, X.-F. Long non-coding RNA LINC00968 attenuates drug resistance of breast cancer cells through inhibiting the Wnt2/ $\beta$-catenin signaling pathway by regulating WNT2. J. Exp. Clin. Cancer Res. 2019, 38, 1-18. [CrossRef]

81. Kladi-Skandali, A.; Michaelidou, K.; Scorilas, A.; Mavridis, K. Long noncoding RNAs in digestive system malignancies: A novel class of cancer biomarkers and therapeutic targets? Gastroenterol. Res. Pract. 2015, 2015, 319861. [CrossRef] [PubMed]

82. Arriaga-Canon, C.; De La Rosa-Velázquez, I.A.; González-Barrios, R.; Montiel-Manríquez, R.; Oliva-Rico, D.; Jiménez-Trejo, F.; Cortés-González, C.; Herrera, L.A. The use of long non-coding RNAs as prognostic biomarkers and therapeutic targets in prostate cancer. Oncotarget 2018, 9, 20872. [CrossRef]

83. Gao, J.; Wang, F.; Wu, P.; Chen, Y.; Jia, Y. Aberrant LncRNA expression in leukemia. J. Cancer 2020, 11, 4284. [CrossRef] [PubMed]

84. Guzel, E.; Okyay, T.M.; Yalcinkaya, B.; Karacaoglu, S.; Gocmen, M.; Akcakuyu, M.H. Tumor suppressor and oncogenic role of long non-coding RNAs in cancer. North. Clin. Istanb. 2020, 7, 81. [CrossRef] [PubMed]

85. Duan, Y.; Wang, Z.; Xu, L.; Sun, L.; Song, H.; Yin, H.; He, F. lncRNA SNHG3 acts as a novel Tumor Suppressor and regulates Tumor Proliferation and Metastasis via AKT/mTOR/ERK pathway in Papillary Thyroid Carcinoma. J. Cancer 2020, 11, 3492. [CrossRef] [PubMed]

86. Chen, F.; Li, Y.; Li, M.; Wang, L. Long noncoding RNA GAS5 inhibits metastasis by targeting miR-182/ANGPTL1 in hepatocellular carcinoma. Am. J. Cancer Res. 2019, 9, 108.

87. Zhang, H.; Wei, N.; Zhang, W.; Shen, L.; Ding, R.; Li, Q.; Li, S.; Du, Y. lncRNA SNHG3 promotes breast cancer progression by acting as a miR-326 sponge. Oncol. Rep. 2020, 44, 1502-1510. [CrossRef] [PubMed]

88. Chen, B.W.; Zhou, Y.; Wei, T.; Wen, L.; Zhang, Y.B.; Shen, S.C.; Zhang, J.; Ma, T.; Chen, W.; Ni, L.; et al. miR-182-5p promotes hepatocellular carcinoma progression by repressing FOXO3a. J. Cell. Biochem. 2021, 122, 130-142. [CrossRef] [PubMed]

89. Zhang, Z.; Chen, F.; Zhan, H.; Chen, L.; Deng, Q.; Xiong, T.; Li, Y.; Ye, J. IncRNA CASC9 sponges miR-758-3p to promote proliferation and EMT in bladder cancer by upregulating TGF- $\beta 2$. Oncol. Rep. 2021, 45, 265-277. [CrossRef]

90. Shan, T.D.; Tian, Z.B.; Li, Q.; Jiang, Y.P.; Liu, F.G.; Sun, X.G.; Han, Y.; Sun, L.J.; Chen, L. Long intergenic noncoding RNA 00908 promotes proliferation and inhibits apoptosis of colorectal cancer cells by regulating KLF5 expression. J. Cell. Physiol. 2021, 236, 889-899. [CrossRef] [PubMed]

91. Zhang, F.; Wang, H.; Yu, J.; Yao, X.; Yang, S.; Li, W.; Xu, L.; Zhao, L. LncRNA CRNDE attenuates chemoresistance in gastric cancer via SRSF6-regulated alternative splicing of PICALM. Mol. Cancer 2021, 20, 1-6. [CrossRef] [PubMed]

92. Xiong, M.; Wu, M.; Peng, D.; Huang, W.; Chen, Z.; Ke, H.; Chen, Z.; Song, W.; Zhao, Y.; Xiang, A.P. LncRNA DANCR represses Doxorubicin-induced apoptosis through stabilizing MALAT1 expression in colorectal cancer cells. Cell Death Dis. 2021, 12, 1-17. [CrossRef]

93. Lin, X.; Wu, Z.; Hu, H.; Luo, M.-L.; Song, E. Non-coding RNAs rewire cancer metabolism networks. Semin. Cancer Biol. 2021, 75, 116-126. [CrossRef]

94. Cui, R.; Liu, C.; Lin, P.; Xie, H.; Wang, W.; Zhao, J.; Jiang, S.; Shi, J.; Yu, X. LncRNA AC245100. 4 binds HSP90 to promote the proliferation of prostate cancer. Epigenomics 2020, 12, 1257-1271. [CrossRef]

95. Bin, J.; Nie, S.; Tang, Z.; Kang, A.; Fu, Z.; Hu, Y.; Liao, Q.; Xiong, W.; Zhou, Y.; Tang, Y. Long noncoding RNA EPB41L4A-AS1 functions as an oncogene by regulating the Rho/ROCK pathway in colorectal cancer. J. Cell. Physiol. 2021, 236, 523-535. [CrossRef]

96. Yousefi, H.; Maheronnaghsh, M.; Molaei, F.; Mashouri, L.; Aref, A.R.; Momeny, M.; Alahari, S.K. Long noncoding RNAs and exosomal lncRNAs: Classification, and mechanisms in breast cancer metastasis and drug resistance. Oncogene 2020, 39, 953-974. [CrossRef]

97. Wang, J.-y.; Lu, A.-q.; Chen, L.-j. LncRNAs in ovarian cancer. Clin. Chim. Acta 2019, 490, 17-27. [CrossRef]

98. Xu, T.; Hu, X.-X.; Liu, X.-X.; Wang, H.-J.; Lin, K.; Pan, Y.-Q.; Sun, H.-L.; Peng, H.-X.; Chen, X.-X.; Wang, S.-K. Association between SNPs in long non-coding RNAs and the risk of female breast cancer in a Chinese population. J. Cancer 2017, 8, 1162. [CrossRef]

99. Mansoori, Y.; Tabei, M.B.; Askari, A.; Izadi, P.; Daraei, A.; Bastami, M.; Naghizadeh, M.M.; NarimanmanWang, S.-K. Association bn bcRNAs: Classification, and mechanisms in breast cancer metastasis and drug resis 5 lnc RNA $s$ in cancer-free breast tissue: Molecular associations with age at menarche and obesity. Breast J. 2018, 24, 876-882. [CrossRef] [PubMed]

100. Gerardi, A.N.; Sullivan, I.E. Research on Long-Chain Non-Coding RNA and Breast Cancer: A Review. Int. J. Clin. Exp. Med. Res. 2020, 8, 1015. [CrossRef]

101. Feng, J.; Wen, T.; Li, Z.; Feng, L.; Zhou, L.; Yang, Z.; Xu, L.; Shi, S.; Hou, K.; Shen, J. Cross-talk between the ER pathway and the lncRNA MAFG-AS1/miR-339-5p/CDK2 axis promotes progression of ER+ breast cancer and confers tamoxifen resistance. Aging 2020, 12, 20658. [CrossRef]

102. Cantile, M.; Di Bonito, M.; Cerrone, M.; Collina, F.; De Laurentiis, M.; Botti, G. Long non-coding RNA HOTAIR in breast cancer therapy. Cancers 2020, 12, 1197. [CrossRef] [PubMed]

103. Yuan, C.; Ning, Y.; Pan, Y. Emerging roles of HOTAIR in human cancer. J. Cell. Biochem. 2020, 121, 3235-3247. [CrossRef]

104. Toy, H.I.; Okmen, D.; Kontou, P.I.; Georgakilas, A.G.; Pavlopoulou, A. HOTAIR as a prognostic predictor for diverse human cancers: A meta-and bioinformatics analysis. Cancers 2019, 11, 778. [CrossRef]

105. Obaid, M.; Udden, S.N.; Alluri, P.; Mandal, S.S. LncRNA HOTAIR regulates glucose transporter Glut1 expression and glucose uptake in macrophages during inflammation. Sci. Rep. 2021, 11, 1-19. 
106. Nakashoji, A.; Hayashida, T.; Yamaguchi, S.; Kawai, Y.; Kikuchi, M.; Yokoe, T.; Nagayama, A.; Seki, T.; Takahashi, M.; Kitagawa, Y. Comprehensive analysis of the homeobox family genes in breast cancer demonstrates their similar roles in cancer and development. Breast Cancer Res. Treat. 2021, 186, 1-9. [CrossRef] [PubMed]

107. Arshi, A.; Raeisi, F.; Mahmoudi, E.; Mohajerani, F.; Kabiri, H.; Fazel, R.; Zabihian-Langeroudi, M.; Jusic, A. A Comparative Study of HOTAIR Expression in Breast Cancer Patient Tissues and Cell Lines. Cell J. 2020, 22, 178-184. [PubMed]

108. Zhao, W.; Geng, D.; Li, S.; Chen, Z.; Sun, M. Lnc RNA HOTAIR influences cell growth, migration, invasion, and apoptosis via the miR-20a-5p/HMGA 2 axis in breast cancer. Cancer Med. 2018, 7, 842-855. [CrossRef] [PubMed]

109. Wang, Y.; Gong, G.; Xu, J.; Zhang, Y.; Wu, S.; Wang, S. Long noncoding RNA HOTAIR promotes breast cancer development by targeting ZEB1 via sponging miR-601. Cancer Cell Int. 2020, 20, 1-13. [CrossRef]

110. Zhang, S.; Wang, B.; Xiao, H.; Dong, J.; Li, Y.; Zhu, C.; Jin, Y.; Li, H.; Cui, M.; Fan, S. LncRNA HOTAIR enhances breast cancer radioresistance through facilitating HSPA1A expression via sequestering miR-449b-5p. Thorac. Cancer 2020, 11, 1801-1816. [CrossRef] [PubMed]

111. Zhou, Y.-X.; Wang, C.; Mao, L.-W.; Wang, Y.-L.; Xia, L.-Q.; Zhao, W.; Shen, J.; Chen, J. Long noncoding RNA HOTAIR mediates the estrogen-induced metastasis of endometrial cancer cells via the miR-646/NPM1 axis. Am. J. Physiol-Cell Physiol. 2018, 314, C690-C701. [CrossRef] [PubMed]

112. Zhang, X.-H.; Hu, P.; Xie, Y.-Q.; Kang, Y.-J.; Li, M. Long noncoding RNA HOTAIR promotes endometrial carcinoma cell proliferation by binding to PTEN via the activating phosphatidylinositol 3-kinase/Akt signaling pathway. Mol. Cell. Biol. 2019, 39, e00251-19. [CrossRef]

113. Chi, S.; Liu, Y.; Zhou, X.; Feng, D.; Xiao, X.; Li, W.; Zhao, Y.; Wang, H. Knockdown of long non-coding HOTAIR enhances the sensitivity to progesterone in endometrial cancer by epigenetic regulation of progesterone receptor isoform B. Cancer Chemother. Pharmacol. 2019, 83, 277-287. [CrossRef] [PubMed]

114. Zhou, Y.-H.; Cui, Y.-H.; Wang, T.; Luo, Y. Long non-coding RNA HOTAIR in cervical cancer: Molecular marker, mechanistic insight, and therapeutic target. Adv. Clin. Chem. 2020, 97, 117-140. [PubMed]

115. Li, Q.; Feng, Y.; Chao, X.; Shi, S.; Liang, M.; Qiao, Y.; Wang, B.; Wang, P.; Zhu, Z. HOTAIR contributes to cell proliferation and metastasis of cervical cancer via targetting miR-23b/MAPK1 axis. Biosci. Rep. 2018, 38, BSR20171563. [CrossRef] [PubMed]

116. Liu, M.; Jia, J.; Wang, X.; Liu, Y.; Wang, C.; Fan, R. Long non-coding RNA HOTAIR promotes cervical cancer progression through regulating BCL2 via targeting miR-143-3p. Cancer Biol. Ther. 2018, 19, 391-399. [CrossRef] [PubMed]

117. Saeedi, N.; Ghorbian, S. Analysis of clinical important of LncRNA-HOTAIR gene variations and ovarian cancer susceptibility. Mol. Biol. Rep. 2020, 47, 7421-7427. [CrossRef]

118. Soda, N.; Umer, M.; Kashaninejad, N.; Kasetsirikul, S.; Kline, R.; Salomon, C.; Nguyen, N.-T.; Shiddiky, M.J. PCR-Free Detection of Long Non-Coding HOTAIR RNA in Ovarian Cancer Cell Lines and Plasma Samples. Cancers 2020, 12, 2233. [CrossRef] [PubMed]

119. Yang, C.; Li, H.; Zhang, T.; Chu, Y.; Chen, D.; Zuo, J. miR-200c overexpression inhibits the invasion and tumorigenicity of epithelial ovarian cancer cells by suppressing lncRNA HOTAIR in mice. J. Cell. Biochem. 2020, 121, 1514-1523. [CrossRef] [PubMed]

120. Zhang, Y.; Guo, J.; Cai, E.; Cai, J.; Wen, Y.; Lu, S.; Li, X.; Han, Q.; Jiang, J.; Li, T. HOTAIR maintains the stemness of ovarian cancer stem cells via the miR-206/TBX3 axis. Exp. Cell Res. 2020, 395, 112218. [CrossRef]

121. Jiang, J.; Wang, S.; Wang, Z.; Cai, J.; Han, L.; Xie, L.; Han, Q.; Wang, W.; Zhang, Y.; He, X. HOTAIR promotes paclitaxel resistance by regulating CHEK1 in ovarian cancer. Cancer Chemother. Pharmacol. 2020, 86, 295-305. [CrossRef]

122. Zhao, X.; Cheng, R.; Ouyang, L. Effects of Long Non-coding RNA HOTAIR on the Biological Behaviors of Vulvar Squamous Cell Carcinoma A431 Cells. J. China Med. Univ. 2017, 46, 990-994.

123. Wang, Z.; Li, K.; Huang, W. Long non-coding RNA NEAT1-centric gene regulation. Cell. Mol. Life Sci. 2020, 77, 3769-3779. [CrossRef] [PubMed]

124. Ma, F.; Lei, Y.-Y.; Ding, M.-G.; Luo, L.-H.; Xie, Y.-C.; Liu, X.-L. LncRNA NEAT1 interacted with DNMT1 to regulate malignant phenotype of cancer cell and cytotoxic T cell infiltration via epigenetic inhibition of p53, cGAS, and STING in lung cancer. Front. Genet. 2020, 11, 250. [CrossRef] [PubMed]

125. Jiang, X.; Guo, S.; Zhang, Y.; Zhao, Y.; Li, X.; Jia, Y.; Xu, Y.; Ma, B. LncRNA NEAT1 promotes docetaxel resistance in prostate cancer by regulating ACSL4 via sponging miR-34a-5p and miR-204-5p. Cell. Signal. 2020, 65, 109422. [CrossRef] [PubMed]

126. Shin, V.Y.; Chen, J.; Cheuk, I.W.-Y.; Siu, M.-T.; Ho, C.-W.; Wang, X.; Jin, H.; Kwong, A. Long non-coding RNA NEAT1 confers oncogenic role in triple-negative breast cancer through modulating chemoresistance and cancer stemness. Cell Death Dis. 2019, 10, 1-10. [CrossRef] [PubMed]

127. Yan, L.; Zhang, Z.; Yin, X.; Li, Y. lncRNA NEAT1 facilitates cell proliferation, invasion and migration by regulating CBX7 and RTCB in breast cancer. OncoTargets Ther. 2020, 13, 2449. [CrossRef]

128. Quan, D.; Chen, K.; Zhang, J.; Guan, Y.; Yang, D.; Wu, H.; Wu, S.; Lv, L. Identification of lncRNA NEAT1/miR-21/RRM2 axis as a novel biomarker in breast cancer. J. Cell. Physiol. 2020, 235, 3372-3381. [CrossRef] [PubMed]

129. Li, S.; Hao, J.; Hong, Y.; Mai, J.; Huang, W. Long non-coding RNA NEAT1 promotes the proliferation, migration, and metastasis of human breast-cancer cells by inhibiting miR-146b-5p expression. Cancer Manag. Res. 2020, 12, 6091. [CrossRef]

130. Huang, X.; Zhong, R.; He, X.; Deng, Q.; Peng, X.; Li, J.; Luo, X. Investigations on the mechanism of progesterone in inhibiting endometrial cancer cell cycle and viability via regulation of long noncoding RNA NEAT1/microRNA-146b-5p mediated Wnt/ $\beta$ catenin signaling. IUBMB Life 2019, 71, 223-234. [CrossRef] 
131. Xu, C.; Zhai, J.; Fu, Y. Overexpression of Nuclear Enriched Autosomal Transcript 1 Facilitates Cell Proliferation, Migration Invasion, and Suppresses Apoptosis in Endometrial Cancer by Targeting MicroRNA-202-3p/T Cell Immunoglobulin and Mucin Domain 4 Axis. Cancer Biother. Radiopharm. 2020. [CrossRef]

132. Wang, W.; Ge, L.; Xu, X.-J.; Yang, T.; Yuan, Y.; Ma, X.-L.; Zhang, X.-H. LncRNA NEAT1 promotes endometrial cancer cell proliferation, migration and invasion by regulating the miR-144-3p/EZH2 axis. Radiol. Oncol. 2019, 53, 434-442. [CrossRef] [PubMed]

133. Dong, P.; Xiong, Y.; Yue, J.; Xu, D.; Ihira, K.; Konno, Y.; Kobayashi, N.; Todo, Y.; Watari, H. Long noncoding RNA NEAT1 drives aggressive endometrial cancer progression via miR-361-regulated networks involving STAT3 and tumor microenvironmentrelated genes. J. Exp. Clin. Cancer Res. 2019, 38, 1-15. [CrossRef] [PubMed]

134. Shen, X.; Zhao, W.; Zhang, Y.; Liang, B. Long non-coding RNA-NEAT1 promotes cell migration and invasion via regulating miR-124/NF-kB pathway in cervical cancer. OncoTargets Ther. 2020, 13, 3265. [CrossRef] [PubMed]

135. Zhou, H.; Guo, R.; Wang, C. Long non-coding RNA NEAT1 accelerates cell progression in cervical cancer by regulating the miR-889-3p/E2F7 axis through the activation of the PI3K/AKT pathway. RSC Adv. 2019, 9, 34627-34635. [CrossRef]

136. Yuan, L.Y.; Zhou, M.; Lv, H.; Qin, X.; Zhou, J.; Mao, X.; Li, X.; Xu, Y.; Liu, Y.; Xing, H. Involvement of NEAT1/miR/mi3a axis in promoting cervical cancer progression via targeting SOX4. J. Cell. Physiol. 2019, 234, 18985-18993. [CrossRef] [PubMed]

137. Xie, Q.; Lin, S.; Zheng, M.; Cai, Q.; Tu, Y. Long noncoding RNA NEAT1 promotes the growth of cervical cancer cells via sponging miR-9-5p. Biochem. Cell Biol. 2019, 97, 100-108. [CrossRef]

138. Dong, P.; Xu, D.; Konno, Y.; Ihira, K.; Watari, H. 320 LncRNA NEAT1-mediated miR-361 downregulation contributes to EMT and sphere formation of cervical cancer cells via increasing HSP90 expression. BMJ J. 2020, 30, A128-A129. [CrossRef]

139. Yuan, J.; Yi, K.; Yang, L. LncRNA NEAT1 promotes proliferation of ovarian cancer cells and angiogenesis of co-incubated human umbilical vein endothelial cells by regulating FGF9 through sponging miR-365: An experimental study. Medicine 2021, 100, e23423. [CrossRef] [PubMed]

140. Luo, M.; Zhang, L.; Yang, H.; Luo, K.; Qing, C. Long non-coding RNA NEAT1 promotes ovarian cancer cell invasion and migration by interacting with miR-1321 and regulating tight junction protein 3 expression. Mol. Med. Rep. 2020, 22, 3429-3439. [CrossRef]

141. Xu, H.; Sun, X.; Huang, Y.; Si, Q.; Li, M. Long non-coding RNA NEAT1 modifies cell proliferation, colony formation, apoptosis, migration and invasion via the miR-4500/BZW1 axis in ovarian cancer. Mol. Med. Rep. 2020, 22, 3347-3357. [CrossRef]

142. Yong, W.; Yu, D.; Jun, Z.; Yachen, D.; Weiwei, W.; Midie, X.; Xingzhu, J.; Xiaohua, W. Long noncoding RNA NEAT1, regulated by LIN28B, promotes cell proliferation and migration through sponging miR-506 in high-grade serous ovarian cancer. Cell Death Dis. 2018, 9, 1-15. [CrossRef]

143. Zhu, M.; Yang, L.; Wang, X. NEAT1 Knockdown Suppresses the Cisplatin Resistance in Ovarian Cancer by Regulating miR-7705p/PARP1 Axis. Cancer Manag. Res. 2020, 12, 7277. [CrossRef]

144. Wu, M.; Li, J.; Ma, Y.; Lin, Z. 321 Comparison of two types of triple incision technique in the treatment of patients with locally advanced vulvar cancer. IJGC 2020, 30, A129-A130.

145. Hashemi, M.; Moazeni-Roodi, A.; Sarabandi, S.; Karami, S.; Ghavami, S. Association between genetic polymorphisms of long noncoding RNA H19 and cancer risk: A meta-analysis. J. Genet. 2019, 98, 1-11. [CrossRef]

146. Tietze, L.; Kessler, S.M. The Good, the Bad, the Question-H19 in Hepatocellular Carcinoma. Cancers 2020, 12, 1261. [CrossRef]

147. Yoshimura, H.; Matsuda, Y.; Yamamoto, M.; Kamiya, S.; Ishiwata, T. Expression and role of long non-coding RNA H19 in carcinogenesis. Front. Biosci. 2018, 23, 614-625.

148. Wu, E.-R.; Chou, Y.-E.; Liu, Y.-F.; Hsueh, K.-C.; Lee, H.-L.; Yang, S.-F.; Su, S.-C. Association of lncRNA H19 gene polymorphisms with the occurrence of hepatocellular carcinoma. Genes 2019, 10, 506. [CrossRef]

149. Liu, C.; Chen, L.; You, Z.; Wu, Y.; Wang, C.; Zhang, G.; Xu, B.; Chen, M. Association between lncRNA H19 polymorphisms and cancer susceptibility based on a meta-analysis from 25 studies. Gene 2020, 729, 144317. [CrossRef]

150. Deng, Y.; Zhou, L.; Yao, J.; Liu, Y.; Zheng, Y.; Yang, S.; Wu, Y.; Li, N.; Xu, P.; Lyu, L. Associations of lncRNA H19 polymorphisms at microrna binding sites with glioma susceptibility and prognosis. Mol. Ther-Nucleic Acids 2020, 20, 86-96. [CrossRef] [PubMed]

151. Lim, Y.W.S.; Xiang, X.; Garg, M.; Le, M.T.; Wong, A.L.-A.; Wang, L.; Goh, B.-C. The double-edged sword of H19 lncRNA: Insights into cancer therapy. Cancer Lett. 2020, 500, 253-262.

152. Alipoor, B.; Parvar, S.N.; Sabati, Z.; Ghaedi, H.; Ghasemi, H. An updated review of the H19 lncRNA in human cancer: Molecular mechanism and diagnostic and therapeutic importance. Mol. Biol. Rep. 2020, 47, 6357-6374. [CrossRef]

153. Peperstraete, E.; Lecerf, C.; Collette, J.; Vennin, C.; Raby, L.; Völkel, P.; Angrand, P.-O.; Winter, M.; Bertucci, F.; Finetti, P. Enhancement of Breast Cancer Cell Aggressiveness by lncRNA H19 and its Mir-675 Derivative: Insight into Shared and Different Actions. Cancers 2020, 12, 1730. [CrossRef] [PubMed]

154. Elias-Rizk, T.; El Hajj, J.; Segal-Bendirdjian, E.; Hilal, G. The long non coding RNA H19 as a biomarker for breast cancer diagnosis in Lebanese women. Sci. Rep. 2020, 10, 1-7. [CrossRef]

155. Xiong, H.; Shen, J.; Chen, Z.; Yang, J.; Xie, B.; Jia, Y.; Jayasinghe, U.; Wang, J.; Zhao, W.; Xie, S. H19/let-7/Lin28 ceRNA network mediates autophagy inhibiting epithelial-mesenchymal transition in breast cancer. Int. J. Oncol. 2020, 56, 794-806. [CrossRef] [PubMed]

156. Li, Y.; Ma, H.-Y.; Hu, X.-W.; Qu, Y.-Y.; Wen, X.; Zhang, Y.; Xu, Q.-Y. LncRNA H19 promotes triple-negative breast cancer cells invasion and metastasis through the p53/TNFAIP8 pathway. Cancer Cell Int. 2020, 20, 1-14. [CrossRef] 
157. Zhang, L.; Wang, D.; Yu, P. LncRNA H19 regulates the expression of its target gene HOXA10 in endometrial carcinoma through competing with miR-612. Eur. Rev. Med. Pharmacol. Sci. 2018, 22, 4820-4827. [PubMed]

158. Zhao, L.; Li, Z.; Chen, W.; Zhai, W.; Pan, J.; Pang, H.; Li, X. H19 promotes endometrial cancer progression by modulating epithelial-mesenchymal transition. Oncol. Lett. 2017, 13, 363-369. [CrossRef]

159. Dong, P.; Xiong, Y.; Yue, J.; JB Hanley, S.; Kobayashi, N.; Todo, Y.; Watari, H. Exploring lncRNA-mediated regulatory networks in endometrial cancer cells and the tumor microenvironment: Advances and challenges. Cancers 2019, 11, 234. [CrossRef]

160. Zhu, H.; Jin, Y.-M.; Lyu, X.-M.; Fan, L.-M.; Wu, F. Long noncoding RNA H19 regulates HIF-1 $\alpha /$ AXL signaling through inhibiting miR-20b-5p in endometrial cancer. Cell Cycle 2019, 18, 2454-2464. [CrossRef]

161. Roychowdhury, A.; Samadder, S.; Das, P.; Mazumder, D.I.; Chatterjee, A.; Addya, S.; Mondal, R.; Roy, A.; Roychoudhury, S.; Panda, C.K. Deregulation of H19 is associated with cervical carcinoma. Genomics 2020, 112, 961-970. [CrossRef]

162. Lee, C.; Kim, S.J.; Na, J.Y.; Park, C.S.; Lee, S.Y.; Kim, I.H.; Oh, Y.K. Alterations in promoter usage and expression levels of insulin-like growth factor-II and H19 genes in cervical and endometrial cancer. Cancer Res. Treat. 2003, 35, 314-322. [CrossRef]

163. Ou, L.; Wang, D.; Zhang, H.; Yu, Q.; Hua, F. Decreased expression of miR-138-5p by lncRNA H19 in cervical cancer promotes tumor proliferation. Oncol. Res. Featur. Preclin. Clin. Cancer Ther. 2018, 26, 401-410. [CrossRef] [PubMed]

164. Chen, C.-L.; Ip, S.-M.; Cheng, D.; Wong, L.-C.; Ngan, H.Y. Loss of imprinting of the IGF-II and H19 genes in epithelial ovarian cancer. Clin. Cancer Res. 2000, 6, 474-479. [PubMed]

165. Li, J.; Huang, Y.; Deng, X.; Luo, M.; Wang, X.; Hu, H.; Liu, C.; Zhong, M. Long noncoding RNA H19 promotes transforming growth factor- $\beta$-induced epithelial-mesenchymal transition by acting as a competing endogenous RNA of miR-370-3p in ovarian cancer cells. OncoTargets Ther. 2018, 11, 427. [CrossRef] [PubMed]

166. Sajadpoor, Z.; Amini-Farsani, Z.; Teimori, H.; Shamsara, M.; Sangtarash, M.H.; Ghasemi-Dehkordi, P.; Yadollahi, F. Valproic acid promotes apoptosis and cisplatin sensitivity through downregulation of H19 noncoding RNA in ovarian A2780 cells. Appl. Biochem. Biotechnol. 2018, 185, 1132-1144. [CrossRef]

167. Zeng, Y.; Li, T.-L.; Zhang, H.-B.; Deng, J.-L.; Zhang, R.; Sun, H.; Wan, Z.-R.; Liu, Y.-Z.; Zhu, Y.-S.; Wang, G. Polymorphisms in IGF2/H19 gene locus are associated with platinum-based chemotherapeutic response in Chinese patients with epithelial ovarian cancer. Pharmacogenomics 2019, 20, 179-188. [CrossRef]

168. Arima, T.; Matsuda, T.; Takagi, N.; Wake, N. Association of IGF2 and H19 imprinting with choriocarcinoma development. Cancer Genet. Cytogenet. 1997, 93, 39-47. [CrossRef]

169. Yu, L.-L.; Chang, K.; Lu, L.-S.; Zhao, D.; Han, J.; Zheng, Y.-R.; Yan, Y.-H.; Yi, P.; Guo, J.-X.; Zhou, Y.-G. Lentivirus-mediated RNA interference targeting the $\mathrm{H} 19$ gene inhibits cell proliferation and apoptosis in human choriocarcinoma cell line JAR. BMC Cell Biol. 2013, 14, 1-9. [CrossRef]

170. Yu, S.; Wu, C.; Tan, Q.; Liu, H. Long noncoding RNA H19 promotes chemotherapy resistance in choriocarcinoma cells. J. Cell. Biochem. 2019, 120, 15131-15144. [CrossRef]

171. Sun, Y.; Ma, L. New insights into long non-coding RNA MALAT1 in cancer and metastasis. Cancers 2019, 11, 216. [CrossRef]

172. Arun, G.; Aggarwal, D.; Spector, D.L. MALAT1 long non-coding RNA: Functional implications. Non-Coding RNA 2020, 6, 22. [CrossRef] [PubMed]

173. Stone, J.K.; Kim, J.-H.; Vukadin, L.; Richard, A.; Giannini, H.K.; Lim, S.-T.S.; Tan, M.; Ahn, E.-Y.E. Hypoxia induces cancer cell-specific chromatin interactions and increases MALAT1 expression in breast cancer cells. J. Biol. Chem. 2019, 294, 11213-11224. [CrossRef]

174. Kang, Y.-J.; Yang, D.-C.; Kong, L.; Hou, M.; Meng, Y.-Q.; Wei, L.; Gao, G. CPC2: A fast and accurate coding potential calculator based on sequence intrinsic features. Nucleic Acids Res. 2017, 45, W12-W16. [CrossRef]

175. Fei, J.; Jadaliha, M.; Harmon, T.S.; Li, I.T.; Hua, B.; Hao, Q.; Holehouse, A.S.; Reyer, M.; Sun, Q.; Freier, S.M. Quantitative analysis of multilayer organization of proteins and RNA in nuclear speckles at super resolution. J. Cell Sci. 2017, 130, 4180-4192. [CrossRef]

176. Chen, Q.; Zhu, C.; Jin, Y. The oncogenic and tumor suppressive functions of the long noncoding RNA MALAT1: An emerging controversy. Front. Genet. 2020, 11, 93. [CrossRef]

177. Arun, G.; Diermeier, S.D.; Spector, D.L. Therapeutic targeting of long non-coding RNAs in cancer. Trends Mol. Med. 2018, 24, 257-277. [CrossRef] [PubMed]

178. Luo, W.; He, H.; Xiao, W.; Liu, Q.; Deng, Z.; Lu, Y.; Wang, Q.; Zheng, Q.; Li, Y. MALAT1 promotes osteosarcoma development by targeting TGFA via MIR376A. Oncotarget 2016, 7, 54733. [CrossRef]

179. Zhang, Z.; Li, M.; Zhang, Z. IncRNA MALAT1 modulates oxaliplatin resistance of gastric cancer via sponging miR-22-3p. OncoTargets Ther. 2020, 13, 1343. [CrossRef] [PubMed]

180. Ji, P.; Diederichs, S.; Wang, W.; Böing, S.; Metzger, R.; Schneider, P.M.; Tidow, N.; Brandt, B.; Buerger, H.; Bulk, E. MALAT-1, a novel noncoding RNA, and thymosin $\beta 4$ predict metastasis and survival in early-stage non-small cell lung cancer. Oncogene 2003, 22, 8031-8041. [CrossRef] [PubMed]

181. Peng, Y.; Fang, X.; Yao, H.; Zhang, Y.; Shi, J. MiR-146b-5p Regulates the Expression of Long Noncoding RNA MALAT1 and Its Effect on the Invasion and Proliferation of Papillary Thyroid Cancer. Cancer Biother. Radiopharm. 2020, 36, 433-440. [CrossRef]

182. Pa, M.; Naizaer, G.; Seyiti, A.; Kuerbang, G. Long noncoding RNA MALAT1 functions as a sponge of MiR-200c in ovarian cancer. Oncol. Res. Featur. Preclin. Clin. Cancer Ther. 2020. [CrossRef]

183. Hu, C.; Sun, Y.; Yang, X. Pioglitazone up-regulates MALAT1 and promotes the proliferation of endothelial progenitor cells through increasing c-Myc expression in type 2 diabetes mellitus. Aging Pathobiol. Ther. 2020, 2, 38-44. [CrossRef] 
184. Hao, Y.; Yan, Z.; Zhang, A.; Hu, S.; Wang, N.; Luo, X.-G.; Ma, W.; Zhang, T.-C.; He, H. IL-6/STAT3 mediates the HPV18 E6/E7 stimulated upregulation of MALAT1 gene in cervical cancer HeLa cells. Virus Res. 2020, 281, 197907. [CrossRef] [PubMed]

185. Ni, W.; Wang, X.; Sun, Y.; Gao, X. Meta-analysis of the association between MALAT1 rs619586 A > G polymorphism and cancer risk. J. Int. Med. Res. 2020, 48, 0300060520941969. [CrossRef] [PubMed]

186. Kim, J.; Piao, H.-L.; Kim, B.-J.; Yao, F.; Han, Z.; Wang, Y.; Xiao, Z.; Siverly, A.N.; Lawhon, S.E.; Ton, B.N. Long noncoding RNA MALAT1 suppresses breast cancer metastasis. Nat. Genet. 2018, 50, 1705-1715. [CrossRef] [PubMed]

187. Sun, Z.; Liu, J.; Liu, J. The expression of lncRNA-MALAT1 in breast cancer patients and its influences on prognosis. Cell. Mol. Biol. 2020, 66, 72-78. [CrossRef] [PubMed]

188. Goyal, B.; Yadav, S.R.M.; Awasthee, N.; Gupta, S.; Kunnumakkara, A.B.; Gupta, S.C. Diagnostic, prognostic, and therapeutic significance of long non-coding RNA MALAT1 in cancer. Biochim. Biophys. Acta (BBA) Rev. Cancer 2021, 1875, 188502. [CrossRef] [PubMed]

189. Chou, J.; Wang, B.; Zheng, T.; Li, X.; Zheng, L.; Hu, J.; Zhang, Y.; Xing, Y.; Xi, T. MALAT1 induced migration and invasion of human breast cancer cells by competitively binding miR-1 with cdc42. Biochem. Biophys. Res. Commun. 2016, 472, 262-269. [CrossRef]

190. Bamodu, O.A.; Huang, W.-C.; Lee, W.-H.; Wu, A.; Wang, L.S.; Hsiao, M.; Yeh, C.-T.; Chao, T.-Y. Aberrant KDM5B expression promotes aggressive breast cancer through MALAT1 overexpression and downregulation of hsa-miR-448. BMC Cancer 2016, 16, 1-18. [CrossRef]

191. Dolatabadi, N.F.; Dehghani, A.; Shahand, E.; Yazdanshenas, M.; Tabatabaeian, H.; Zamani, A.; Azadeh, M.; Ghaedi, K. The interaction between MALAT1 target, miR-143-3p, and RALGAPA2 is affected by functional SNP rs3827693 in breast cancer. Human Cell 2020, 33, 1229-1239. [CrossRef] [PubMed]

192. Huang, X.J.; Xia, Y.; He, G.F.; Zheng, L.L.; Cai, Y.P.; Yin, Y.; Wu, Q. MALAT1 promotes angiogenesis of breast cancer. Oncol. Rep. 2018, 40, 2683-2689. [CrossRef] [PubMed]

193. Li, X.; Chen, N.; Zhou, L.; Wang, C.; Wen, X.; Jia, L.; Cui, J.; Hoffman, A.R.; Hu, J.-F.; Li, W. Genome-wide target interactome profiling reveals a novel EEF1A1 epigenetic pathway for oncogenic lncRNA MALAT1 in breast cancer. Am. J. Cancer Res. 2019, 9, 714. [PubMed]

194. Xiping, Z.; Bo, C.; Shifeng, Y.; Feijiang, Y.; Hongjian, Y.; Qihui, C.; Binbin, T. Roles of MALAT1 in development and migration of triple negative and Her-2 positive breast cancer. Oncotarget 2018, 9, 2255. [CrossRef]

195. Wu, Y.; Sarkissyan, M.; Ogah, O.; Kim, J.; Vadgama, J.V. Expression of MALAT1 Promotes Trastuzumab Resistance in HER2 Overexpressing Breast Cancers. Cancers 2020, 12, 1918. [CrossRef]

196. Zhao, Y.; Yu, Y.-q.; You, S.; Zhang, C.-m.; Wu, L.; Zhao, W.; Wang, X.-m. Long Non-Coding RNA MALAT1 as a Detection and Diagnostic Molecular Marker in Various Human Cancers: A Pooled Analysis Based on 3255 Subjects. OncoTargets Ther. 2020, 13, 5807. [CrossRef] [PubMed]

197. Chen, G.; Zhang, M.; Liang, Z.; Chen, S.; Chen, F.; Zhu, J.; Zhao, M.; He, J.; Hua, W.; Duan, P. Association of polymorphisms in MALAT1 with the risk of endometrial cancer in Southern Chinese women. J. Clin. Lab. Anal. 2020, 34, e23146. [CrossRef] [PubMed]

198. Li, Q.; Zhang, C.; Chen, R.; Xiong, H.; Qiu, F.; Liu, S.; Zhang, M.; Wang, F.; Wang, Y.; Zhou, X. Disrupting MALAT1/miR-200c sponge decreases invasion and migration in endometrioid endometrial carcinoma. Cancer Lett. 2016, 383, 28-40. [CrossRef] [PubMed]

199. Zhao, Y.; Yang, Y.; Trovik, J.; Sun, K.; Zhou, L.; Jiang, P.; Lau, T.-S.; Hoivik, E.A.; Salvesen, H.B.; Sun, H. A novel wnt regulatory axis in endometrioid endometrial cancer. Cancer Res. 2014, 74, 5103-5117. [CrossRef]

200. Shen, Y.; Mengjun, S.; Lin, L.; Ding, X.; Sun, Y.; Zhang, J.; He, A.; Wang, Y.; Zhou, Y.; Su, Y. MALAT1 plays important role in MEK inhibitor, RG7420, on the proliferation and migration of endometrial cancer cell through sponging miR-129-5p/TAK1. Res. Sq. 2020. [CrossRef]

201. Wang, M.C.; McCown, P.J.; Schiefelbein, G.E.; Brown, J.A. Secondary Structural Model of MALAT1 Becomes Unstructured in Chronic Myeloid Leukemia and Undergoes Structural Rearrangement in Cervical Cancer. Non-Coding RNA 2021, 7, 6. [CrossRef] [PubMed]

202. Lu, H.; He, Y.; Lin, L.; Qi, Z.; Ma, L.; Li, L.; Su, Y. Long non-coding RNA MALAT1 modulates radiosensitivity of HR-HPV+ cervical cancer via sponging miR-145. Tumor Biol. 2016, 37, 1683-1691. [CrossRef] [PubMed]

203. Han, X.; Wang, Q.; Wang, Y.; Hu, B.; Dong, X.; Zhang, H.; Wang, W. Long non-coding RNA metastasis-associated lung adenocarcinoma transcript $1 /$ microRNA-202-3p/periostin axis modulates invasion and epithelial-mesenchymal transition in human cervical cancer. J. Cell. Physiol. 2019, 234, 14170-14180. [CrossRef] [PubMed]

204. Shen, F.; Zheng, H.; Zhou, L.; Li, W.; Xu, X. Overexpression of MALAT1 contributes to cervical cancer progression by acting as a sponge of miR-429. J. Cell. Physiol. 2019, 234, 11219-11226. [CrossRef] [PubMed]

205. Li, Y.; Ding, Y.; Ding, N.; Zhang, H.; Lu, M.; Cui, X.; Yu, X. MicroRNA-625-5p sponges lncRNA MALAT1 to inhibit cervical carcinoma cell growth by suppressing NF-kB signaling. Cell Biochem. Biophys. 2020, 78, 217-225. [CrossRef] [PubMed]

206. Wang, N.; Hou, M.; Zhan, Y.; Shen, X.; Xue, H. MALAT1 promotes cisplatin resistance in cervical cancer by activating the PI3K/AKT pathway. Eur. Rev. Med. Pharmacol. Sci. 2018, 22, 7653-7659. [PubMed] 
207. Wu, X.; Wang, Y.; Zhong, W.; Cheng, H.; Tian, Z. The long non-coding RNA MALAT1 enhances ovarian cancer cell stemness by inhibiting YAP translocation from nucleus to cytoplasm. Med. Sci. Monit. Int. Med. J. Exp. Clin. Res. 2020, 26, e922012-1-e922012-9. [CrossRef] [PubMed]

208. Bai, L.; Wang, A.; Zhang, Y.; Xu, X.; Zhang, X. Knockdown of MALAT1 enhances chemosensitivity of ovarian cancer cells to cisplatin through inhibiting the Notch1 signaling pathway. Exp. Cell Res. 2018, 366, 161-171. [CrossRef]

209. Lin, Q.; Guan, W.; Ren, W.; Zhang, L.; Zhang, J.; Xu, G. MALAT1 affects ovarian cancer cell behavior and patient survival. Oncol. Rep. 2018, 39, 2644-2652. [CrossRef] [PubMed]

210. Sun, Q.; Li, Q.; Xie, F. LncRNA-MALAT1 regulates proliferation and apoptosis of ovarian cancer cells by targeting miR-503-5p. OncoTargets Ther. 2019, 12, 6297. [CrossRef] [PubMed]

211. Gordon, M.A.; Babbs, B.; Cochrane, D.R.; Bitler, B.G.; Richer, J.K. The long non-coding RNA MALAT1 promotes ovarian cancer progression by regulating RBFOX2-mediated alternative splicing. Mol. Carcinog. 2019, 58, 196-205. [CrossRef]

212. Guo, C.; Wang, X.; Chen, L.; Li, M.; Li, M.; Hu, Y.; Ding, W.; Wang, X. Long non-coding RNA MALAT1 regulates ovarian cancer cell proliferation, migration and apoptosis through Wnt/beta-catenin signaling pathway. Eur. Rev. Med. Pharmacol. Sci. 2018, 22, 3703-3712. [PubMed]

213. Liao, H.; Chen, Q.; Xiao, J. Reflections on the Role of Malat1 in Gynecological Cancer. Cancer Manag. Res. 2020, $12,13489$. [CrossRef] [PubMed]

214. Lei, L.; Chen, J.; Huang, J.; Lu, J.; Pei, S.; Ding, S.; Kang, L.; Xiao, R.; Zeng, Q. Functions and regulatory mechanisms of metastasis-associated lung adenocarcinoma transcript 1. J. Cell. Physiol. 2019, 234, 134-151. [CrossRef]

215. Shi, D.; Zhang, Y.; Lu, R.; Zhang, Y. The long non-coding RNA MALAT1 interacted with miR-218 modulates choriocarcinoma growth by targeting Fbxw8. Biomed. Pharmacother. 2018, 97, 543-550. [CrossRef]

216. He, C.; Yang, W.; Yang, J.; Ding, J.; Li, S.; Wu, H.; Zhou, F.; Jiang, Y.; Teng, L.; Yang, J. Long noncoding RNA MEG3 negatively regulates proliferation and angiogenesis in vascular endothelial cells. DNA Cell Biol. 2017, 36, 475-481. [CrossRef] [PubMed]

217. Sun, H.; Peng, G.; Wu, H.; Liu, M.; Mao, G.; Ning, X.; Yang, H.; Deng, J. Long non-coding RNA MEG3 is involved in osteogenic differentiation and bone diseases. Biomed. Rep. 2020, 13, 15-21. [CrossRef]

218. Tan, M.C.; Widagdo, J.; Chau, Y.Q.; Zhu, T.; Wong, J.J.-L.; Cheung, A.; Anggono, V. The activity-induced long non-coding RNA Meg3 modulates AMPA receptor surface expression in primary cortical neurons. Front. Cell. Neurosci. 2017, 11, 124. [CrossRef]

219. Benetatos, L.; Vartholomatos, G.; Hatzimichael, E. MEG3 imprinted gene contribution in tumorigenesis. Int. J. Cancer 2011, 129, 773-779. [CrossRef]

220. Wallace, C.; Smyth, D.J.; Maisuria-Armer, M.; Walker, N.M.; Todd, J.A.; Clayton, D.G. The imprinted DLK1-MEG3 gene region on chromosome 14q32. 2 alters susceptibility to type 1 diabetes. Nat. Genet. 2010, 42, 68. [CrossRef]

221. Goovaerts, T.; Steyaert, S.; Vandenbussche, C.A.; Galle, J.; Thas, O.; Van Criekinge, W.; De Meyer, T. A comprehensive overview of genomic imprinting in breast and its deregulation in cancer. Nat. Commun. 2018, 9, 1-14. [CrossRef]

222. Hou, Y.; Zhang, B.; Miao, L.; Ji, Y.; Yu, Y.; Zhu, L.; Ma, H.; Yuan, H. Association of long non-coding RNA MEG3 polymorphisms with oral squamous cell carcinoma risk. Oral Dis. 2019, 25, 1318-1324. [CrossRef]

223. Al-Rugeebah, A.; Alanazi, M.; Parine, N.R. MEG3: An oncogenic long non-coding RNA in different cancers. Pathol. Oncol. Res. 2019, 25, 859-874. [CrossRef]

224. Xiu, Y.-1.; Sun, K.-x.; Chen, X.; Chen, S.; Zhao, Y.; Guo, Q.-g.; Zong, Z.-H. Upregulation of the lncRNA Meg3 induces autophagy to inhibit tumorigenesis and progression of epithelial ovarian carcinoma by regulating activity of ATG3. Oncotarget 2017, 8,31714 . [CrossRef]

225. Zheng, Y.; Wang, M.; Wang, S.; Xu, P.; Deng, Y.; Lin, S.; Li, N.; Liu, K.; Zhu, Y.; Zhai, Z. LncRNA MEG3 rs3087918 was associated with a decreased breast cancer risk in a Chinese population: A case-control study. BMC Cancer 2020, 20, 1-8. [CrossRef]

226. Zhang, Y.; Wu, J.; Jing, H.; Huang, G.; Sun, Z.; Xu, S. Long noncoding RNA MEG3 inhibits breast cancer growth via upregulating endoplasmic reticulum stress and activating NF S. Long no. J. Cell. Biochem. 2019, 120, 6789-6797. [CrossRef]

227. Bayarmaa, B.; Wu, Z.; Peng, J.; Wang, Y.; Xu, S.; Yan, T.; Yin, W.; Lu, J.; Zhou, L. Association of LncRNA MEG3 polymorphisms with efficacy of neoadjuvant chemotherapy in breast cancer. BMC Cancer 2019, 19, 1-8. [CrossRef] [PubMed]

228. Zhu, M.; Wang, F.; Mi, H.; Li, L.; Wang, J.; Han, M.; Gu, Y. Long noncoding RNA MEG3 suppresses cell proliferation, migration and invasion, induces apoptosis and paclitaxel-resistance via miR-4513/PBLD axis in breast cancer cells. Cell Cycle 2020, 19, 3277-3288. [CrossRef] [PubMed]

229. Ali, M.A.; Shaker, O.G.; Alazrak, M.; AbdelHafez, M.N.; Khalefa, A.A.; Hemeda, N.F.; Abdelmoktader, A.; Ahmed, F.A. Association analyses of a genetic variant in long non-coding RNA MEG3 with breast cancer susceptibility and serum MEG3 expression level in the Egyptian population. Cancer Biomark. 2020, 28, 49-63. [CrossRef] [PubMed]

230. Li, H.; Wang, P.; Liu, J.; Liu, W.; Wu, X.; Ding, J.; Kang, J.; Li, J.; Lu, J.; Pan, G. Hypermethylation of lncRNA MEG3 impairs chemosensitivity of breast cancer cells. J. Clin. Lab. Anal. 2020, 34, e23369. [CrossRef]

231. Wang, R.; Zou, L. Downregulation of LncRNA-MEG3 promotes HTR8/SVneo cells apoptosis and attenuates its migration by repressing Notch1 signal in preeclampsia. Reproduction 2020, 160, 21-29. [CrossRef] [PubMed]

232. Guo, Q.; Qian, Z.; Yan, D.; Li, L.; Huang, L. LncRNA-MEG3 inhibits cell proliferation of endometrial carcinoma by repressing Notch signaling. Biomed. Pharmacother. 2016, 82, 589-594. [CrossRef] [PubMed]

233. Sun, K.-X.; Wu, D.-D.; Chen, S.; Zhao, Y.; Zong, Z.-H. LncRNA MEG3 inhibit endometrial carcinoma tumorigenesis and progression through PI3K pathway. Apoptosis 2017, 22, 1543-1552. [CrossRef] 
234. Xu, D.; Dong, P.; Xiong, Y.; Chen, R.; Konno, Y.; Ihira, K.; Yue, J.; Watari, H. PD-L1 is a tumor suppressor in aggressive endometrial cancer cells and its expression is regulated by miR-216a and lncRNA MEG3. Front. Cell Dev. Biol. 2020, 8, 598205. [CrossRef] [PubMed]

235. Wan, S.; Zhao, H. Analysis of diagnostic and prognostic value of lncRNA MEG3 in cervical cancer. Oncol. Lett. 2020, $20,183$. [CrossRef] [PubMed]

236. Tornesello, M.L.; Faraonio, R.; Buonaguro, L.; Annunziata, C.; Starita, N.; Cerasuolo, A.; Pezzuto, F.; Tornesello, A.L.; Buonaguro, F.M. The role of microRNAs, long non-coding RNAs, and circular RNAs in cervical cancer. Front. Oncol. 2020, 10, 150. [CrossRef]

237. Zhang, J.; Yao, T.; Wang, Y.; Yu, J.; Liu, Y.; Lin, Z. Long noncoding RNA MEG3 is downregulated in cervical cancer and affects cell proliferation and apoptosis by regulating miR-21. Cancer Biol. Ther. 2016, 17, 104-113. [CrossRef]

238. Pan, X.; Cao, Y.-M.; Liu, J.-H.; Ding, J.; Xie, X.-Y.; Cao, P.-G. MEG3 Induces Cervical Carcinoma Cell's Apoptosis Through Endoplasmic Reticulum Stress by miR-7-5p/STC1 Axis. Cancer Biother. Radiopharm. 2021, 36, 501-510. [CrossRef] [PubMed]

239. Zhang, J.; Gao, Y. Long non-coding RNA MEG3 inhibits cervical cancer cell growth by promoting degradation of P-STAT3 protein via ubiquitination. Cancer Cell Int. 2019, 19, 1-10. [CrossRef] [PubMed]

240. Zhu, J.; Han, S. Lidocaine inhibits cervical cancer cell proliferation and induces cell apoptosis by modulating the lncRNAMEG3/miR-421/BTG1 pathway. Am. J. Transl. Res. 2019, 11, 5404. [PubMed]

241. Buttarelli, M.; De Donato, M.; Raspaglio, G.; Babini, G.; Ciucci, A.; Martinelli, E.; Baccaro, P.; Pasciuto, T.; Fagotti, A.; Scambia, G. Clinical value of lncRNA MEG3 in high-grade serous ovarian cancer. Cancers 2020, 12, 966. [CrossRef]

242. Wang, J.; Xu, W.; He, Y.; Xia, Q.; Liu, S. LncRNA MEG3 impacts proliferation, invasion, and migration of ovarian cancer cells through regulating PTEN. Inflamm. Res. 2018, 67, 927-936. [CrossRef] [PubMed]

243. Wang, L.; Yu, M.; Zhao, S. lncRNA MEG3 modified epithelial-mesenchymal transition of ovarian cancer cells by sponging miR-219a-5p and regulating EGFR. J. Cell. Biochem. 2019, 120, 17709-17722. [CrossRef]

244. Tao, P.; Yang, B.; Zhang, H.; Sun, L.; Wang, Y.; Zheng, W. The overexpression of lncRNA MEG3 inhibits cell viability and invasion and promotes apoptosis in ovarian cancer by sponging miR-205-5p. Int. J. Clin. Exp. Pathol. 2020, 13, 869. [PubMed]

245. Liu, Y.; Xu, Y.; Ding, L.; Yu, L.; Zhang, B.; Wei, D. LncRNA MEG3 suppressed the progression of ovarian cancer via sponging miR-30e-3p and regulating LAMA4 expression. Cancer Cell Int. 2020, 20, 1-15. [CrossRef] [PubMed]

246. Ye, W.; Ni, Z.; Yicheng, S.; Pan, H.; Huang, Y.; Xiong, Y.; Liu, T. Anisomycin inhibits angiogenesis in ovarian cancer by attenuating the molecular sponge effect of the lncRNA-Meg3/miR-421/PDGFRA axis. Int. J. Oncol. 2019, 55, 1296-1312. [CrossRef]

247. Ji, L.; Li, X. Long noncoding RNA MEG3 is a tumor suppressor in choriocarcinoma by upregulation of microRNA-211. J. Cell. Physiol. 2019, 234, 22911-22920. [CrossRef]

248. Ji, L.; Ma, L. MEG3 is restored by schisandrin A and represses tumor growth in choriocarcinoma cells. J. Biochem. Mol. Toxicol. 2020, 34, e22455. [CrossRef]

249. Zhang, H.; Wang, J.; Yin, Y.; Meng, Q.; Lyu, Y. The role of EMT-related lncRNA in the process of triple-negative breast cancer metastasis. Biosci. Rep. 2021, 41, BSR20203121. [CrossRef] [PubMed]

250. Ghafouri-Fard, S.; Dashti, S.; Taheri, M. The HOTTIP (HOXA transcript at the distal tip) lncRNA: Review of oncogenic roles in human. Biomed. Pharmacother. 2020, 127, 110158. [CrossRef]

251. Xing, C.; Sun, S.-g.; Yue, Z.-Q.; Bai, F. Role of lncRNA LUCAT1 in cancer. Biomed. Pharmacother. 2021, 134, 111158. [CrossRef] [PubMed]

252. Tang, F.; Xu, Y.; Wang, H.; Bian, E.; Zhao, B. LncRNA-ATB in cancers: What do we know so far? Mol. Biol. Rep. 2020, 47, 4077-4086. [CrossRef] [PubMed]

253. Pourramezan, Z.; Attar, F.A.; Yusefpour, M.; Azizi, M.; Oloomi, M. Circulating LncRNAs Landscape as Potential Biomarkers in Breast Cancer. Res. Sq. 2021. [CrossRef]

254. Zhou, C.; Duan, S. The role of long non-coding RNA NNT-AS1 in neoplastic disease. Cancers 2020, 12, 3086. [CrossRef] [PubMed]

255. Mondal, P.; Meeran, S.M. Long non-coding rnas in breast cancer metastasis. Non-Coding RNA Res. 2020, 5, 208-218. [CrossRef] [PubMed]

256. Wang, N.; Zhang, C.; Wang, W.; Liu, J.; Yu, Y.; Li, Y.; Zhang, M.; Ge, X.; Li, Q.; Miao, L. Long noncoding RNA DANCR regulates proliferation and migration by epigenetically silencing FBP1 in tumorigenesis of cholangiocarcinoma. Cell Death Dis. 2019, 10, 1-11. [CrossRef]

257. Yang, X.; Xie, Z.; Lei, X.; Gan, R. Long non-coding RNA GAS5 in human cancer. Oncol. Lett. 2020, 20, 2587-2594. [CrossRef]

258. Sun, W.; Shen, N.; Fu, S. Involvement of lncRNA-mediated signaling pathway in the development of cervical cancer. Eur. Rev. Med. Pharmacol. Sci. 2019, 23, 3672-3687. [PubMed]

259. Liu, Z.; Wang, Y.; Yuan, S.; Wen, F.; Liu, J.; Zou, L.; Zhang, J. Regulatory role of long non-coding RNA UCA1 in signaling pathways and its clinical applications. Oncol. Lett. 2021, 21, 1-14. [CrossRef]

260. Tu, C.; Ren, X.; He, J.; Zhang, C.; Chen, R.; Wang, W.; Li, Z. The value of LncRNA BCAR4 as a prognostic biomarker on clinical outcomes in human cancers. J. Cancer 2019, 10, 5992. [CrossRef]

261. Han, C.; Fu, Y.; Zeng, N.; Yin, J.; Li, Q. LncRNA FAM83H-AS1 promotes triple-negative breast cancer progression by regulating the miR-136-5p/metadherin axis. Aging 2020, 12, 3594. [CrossRef]

262. Wang, J.; Chen, X.; Hu, H.; Yao, M.; Song, Y.; Yang, A.; Xu, X.; Zhang, N.; Gao, J.; Liu, B. PCAT-1 facilitates breast cancer progression via binding to RACK1 and enhancing oxygen-independent stability of HIF-1 $\alpha$. Mol. Ther.-Nucleic Acids 2021, 24, 310-324. [CrossRef] [PubMed] 
263. Ghafouri-Fard, S.; Kamali, M.J.; Abak, A.; Shoorei, H.; Taheri, M. LncRNA ZFAS1: Role in tumorigenesis and other diseases. Biomed. Pharmacother. 2021, 142, 111999. [CrossRef] [PubMed]

264. Bhardwaj, V.; Tan, Y.Q.; Wu, M.M.; Ma, L.; Zhu, T.; Lobie, P.E.; Pandey, V. Long non-coding RNAs in recurrent ovarian cancer: Theranostic perspectives. Cancer Lett. 2021, 502, 97-107. [CrossRef] [PubMed]

265. Piergentili, R.; Zaami, S.; Cavaliere, A.F.; Signore, F.; Scambia, G.; Mattei, A.; Marinelli, E.; Gulia, C.; Perelli, F. Non-Coding RNAs as Prognostic Markers for Endometrial Cancer. Int. J. Mol. Sci. 2021, 22, 3151. [CrossRef] [PubMed]

266. Liu, D.; Qiu, M.; Jiang, L.; Liu, K. Long noncoding RNA HOXB-AS1 is upregulated in endometrial carcinoma and sponged miR-149-3p to upregulate Wnt10b. Technol. Cancer Res. Treat. 2020, 19, 1533033820967462. [CrossRef]

267. Ghafouri-Fard, S.; Taheri, M. UCA1 long non-coding RNA: An update on its roles in malignant behavior of cancers. Biomed. Pharmacother. 2019, 120, 109459. [CrossRef]

268. Li, Q.; Shen, F.; Zhao, L. The relationship between lncRNA PCGEM1 and STAT3 during the occurrence and development of endometrial carcinoma. Biomed. Pharmacother. 2018, 107, 918-928. [CrossRef]

269. Xu, X.; Zhang, J.; Qi, Y.; Kong, M.; Liu, S.; Hu, J. Linc-ROR promotes endometrial cell proliferation by activating the PI3K-Akt pathway. Eur. Rev. Med. Pharmacol. Sci. 2018, 22, 2218-2225. [PubMed]

270. Ghafouri-Fard, S.; Dashti, S.; Taheri, M. PCAT1: An oncogenic lncRNA in diverse cancers and a putative therapeutic target. Exp. Mol. Pathol. 2020, 114, 104429. [CrossRef] [PubMed]

271. Ke, J.; Shen, Z.; Hu, W.; Li, M.; Shi, Y.; Xie, Z.; Wu, D. LncRNA DCST1-AS1 was upregulated in endometrial carcinoma and may sponge miR-92a-3p to upregulate Notch1. Cancer Manag. Res. 2020, 12, 1221. [CrossRef]

272. Li, Z.; Yu, Z.; Meng, X.; Zhou, S.; Xiao, S.; Li, X.; Liu, S.; Yu, P. Long noncoding RNA GAS5 impairs the proliferation and invasion of endometrial carcinoma induced by high glucose via targeting miR-222-3p/p27. Am. J. Transl. Res. 2019, 11, 2413.

273. Aalijahan, H.; Ghorbian, S. Long non-coding RNAs and cervical cancer. Exp. Mol. Pathol. 2019, 106, 7-16. [CrossRef] [PubMed]

274. Guo, H.; Yang, S.; Li, S.; Yan, M.; Li, L.; Zhang, H. LncRNA SNHG20 promotes cell proliferation and invasion via miR-140-5pADAM10 axis in cervical cancer. Biomed. Pharmacother. 2018, 102, 749-757. [CrossRef] [PubMed]

275. Liu, X.; Xie, S.; Zhang, J.; Kang, Y. Long noncoding RNA XIST contributes to cervical cancer development through targeting miR-889-3p/SIX1 axis. Cancer Biother. Radiopharm. 2020, 35, 640-649. [CrossRef] [PubMed]

276. Berti, F.C.B.; Mathias, C.; Garcia, L.E.; Gradia, D.F.; de Araújo Souza, P.S.; Cipolla, G.A.; de Oliveira, J.C.; Malheiros, D. Comprehensive Analysis of ceRNA Networks in HPV16-and HPV18-mediated Cervical Cancers Reveals XIST as a Pivotal Competing Endogenous RNA. Biochim. Biophys. Acta (BBA)—Mol. Basis Dis. 2021, 1867, 166172. [CrossRef] [PubMed]

277. Gao, F.; Feng, J.; Yao, H.; Li, Y.; Xi, J.; Yang, J. LncRNA SBF2-AS1 promotes the progression of cervical cancer by regulating miR-361-5p/FOXM1 axis. Artif. Cells Nanomed. Biotechnol. 2019, 47, 776-782. [CrossRef] [PubMed]

278. Hu, Y.; Sun, X.; Mao, C.; Guo, G.; Ye, S.; Xu, J.; Zou, R.; Chen, J.; Wang, L.; Duan, P. Upregulation of long noncoding RNA TUG1 promotes cervical cancer cell proliferation and migration. Cancer Med. 2017, 6, 471-482. [CrossRef] [PubMed]

279. Zamaraev, A.V.; Volik, P.I.; Sukhikh, G.T.; Kopeina, G.S.; Zhivotovsky, B. Long non-coding RNAs: A view to kill ovarian cancer. Biochim. Biophys. Acta (BBA)—Rev. Cancer 2021, 1876, 188584. [CrossRef]

280. Gao, Y.; Cheng, H.; Liu, K. Long non-coding RNA DANCR upregulates IGF2 expression and promotes ovarian cancer progression. Eur. Rev. Med. Pharmacol. Sci. 2020, 24, 9239. [PubMed]

281. López-Camarillo, C.; Ruíz-García, E.; Salinas-Vera, Y.M.; Silva-Cázares, M.B.; Hernández-de la Cruz, O.N.; Marchat, L.A.; Gallardo-Rincón, D. Deciphering the Long Non-Coding RNAs and MicroRNAs Coregulation Networks in Ovarian Cancer Development: An Overview. Cells 2021, 10, 1407. [CrossRef] [PubMed]

282. Salamini-Montemurri, M.; Lamas-Maceiras, M.; Barreiro-Alonso, A.; Vizoso-Vázquez, Á.; Rodríguez-Belmonte, E.; QuindósVarela, M.; Cerdán, M.E. The challenges and opportunities of lncRNAs in ovarian cancer research and clinical use. Cancers 2020 12, 1020. [CrossRef] [PubMed]

283. Zhang, S.; Leng, T.; Zhang, Q.; Zhao, Q.; Nie, X.; Yang, L. Sanguinarine inhibits epithelial ovarian cancer development via regulating long non-coding RNA CASC2-EIF4A3 axis and/or inhibiting NF- $\mathrm{kB}$ signaling or PI3K/AKT/mTOR pathway. Biomed. Pharmacother. 2018, 102, 302-308. [CrossRef] [PubMed]

284. Sun, Z.; Gao, S.; Xuan, L.; Liu, X. Long non non.; Yang, L. Sanguinarine inhibits epithelial ovarian cancer development via regulating4 axis. J. Cell. Mol. Med. 2020, 24, 4275-4285. [CrossRef]

285. Lian, Y.; Xu, Y.; Xiao, C.; Xia, R.; Gong, H.; Yang, P.; Chen, T.; Wu, D.; Cai, Z.; Zhang, J. The pseudogene derived from long non-coding RNA DUXAP10 promotes colorectal cancer cell growth through epigenetically silencing of p21 and PTEN. Sci. Rep. 2017, 7, 1-11. [CrossRef] [PubMed]

286. Wang, K.; Hu, Y.-B.; Zhao, Y.; Ye, C. Long non-coding RNA ASAP1-IT1 suppresses ovarian cancer progression by regulating Hippo/YAP signaling. Int. J. Mol. Med. 2021, 47, 1. [CrossRef]

287. Sun, T.; Yang, P.; Gao, Y. Long non-coding RNA EPB41L4A-AS2 suppresses progression of ovarian cancer by sequestering microRNA-103a to upregulate transcription factor RUNX1T1. Exp. Physiol. 2020, 105, 75-87. [CrossRef]

288. Li, J.; Feng, L.; Tian, C.; Tang, Y.; Tang, Y.; Hu, F. Long noncoding RNA-JPX predicts the poor prognosis of ovarian cancer patients and promotes tumor cell proliferation, invasion and migration by the PI3K/Akt/mTOR signaling pathway. Eur. Rev. Med. Pharmacol. Sci. 2018, 22, 8135-8144. [PubMed]

289. Yang, M.; Zhai, Z.; Zhang, Y.; Wang, Y. Clinical significance and oncogene function of long noncoding RNA HAGLROS overexpression in ovarian cancer. Arch. Gynecol. Obstet. 2019, 300, 703-710. [PubMed] 
290. Yue, G.; Chen, C.; Bai, L.; Wang, G.; Huang, Y.; Wang, Y.; Cui, H.; Xiao, Y. Knockdown of long noncoding RNA DLEU1 suppresses the progression of renal cell carcinoma by downregulating the Akt pathway. Mol. Med. Rep. 2019, 20, 4551-4557. [CrossRef] [PubMed]

291. Lou, Y.; Jiang, H.; Cui, Z.; Wang, L.; Wang, X.; Tian, T. Linc-ROR induces epithelial-to-mesenchymal transition in ovarian cancer by increasing W.nt/ $\beta$-catenin signaling. Oncotarget 2017, 8, 69983. [CrossRef] [PubMed]

292. Tu, C.; Ren, X.; He, J.; Li, S.; Qi, L.; Duan, Z.; Wang, W.; Li, Z. The predictive value of lncRNA MIR31HG expression on clinical outcomes in patients with solid malignant tumors. Cancer Cell Int. 2020, 20, 1-13. [CrossRef]

293. Akagi, E.M.; Lavorato-Rocha, A.M.; de Melo Maia, B.; Rodrigues, I.S.; Carvalho, K.C.; Stiepcich, M.M.; Baiocchi, G.; SatoKuwabara, Y.; Rogatto, S.R.; Soares, F.A. ROCK1 as a novel prognostic marker in vulvar cancer. BMC Cancer 2014, 14, 1-10. [CrossRef] [PubMed]

294. Gao, Q.; Fang, X.; Chen, Y.; Li, Z.; Wang, M. Exosomal lncRNA UCA1 from cancerng, X.; ted fibroblasts enhances chemoresistance in vulvar squamous cell carcinoma cells. J. Obstet. Gynaecol. Res. 2021, 47, 73-87. [CrossRef] [PubMed]

295. Di Fiore, R.; Suleiman, S.; Felix, A.; O’Toole, S.A.; O’Leary, J.J.; Ward, M.P.; Beirne, J.; Sabol, M.; Ozretić, P.; Yordanov, A. An Overview of the Role of Long Non-Coding RNAs in Human Choriocarcinoma. Int. J. Mol. Sci. 2021, 22, 6506. [CrossRef]

296. Cheng, D.; Jiang, S.; Chen, J.; Li, J.; Ao, L.; Zhang, Y. The increased lncRNA MIR503HG in preeclampsia modulated trophoblast cell proliferation, invasion, and migration via regulating matrix metalloproteinases and NF-kB signaling. Dis. Markers 2019, 2019, 1-12. [CrossRef] [PubMed]

297. Gao, N.; Li, Y.; Li, J.; Gao, Z.; Yang, Z.; Li, Y.; Liu, H.; Fan, T. Long Non-Coding RNAs: The regulatory mechanisms, research strategies, and future directions in cancers. Front. Oncol. 2020, 10, 2903. [CrossRef] [PubMed] 